Discussion

Papers

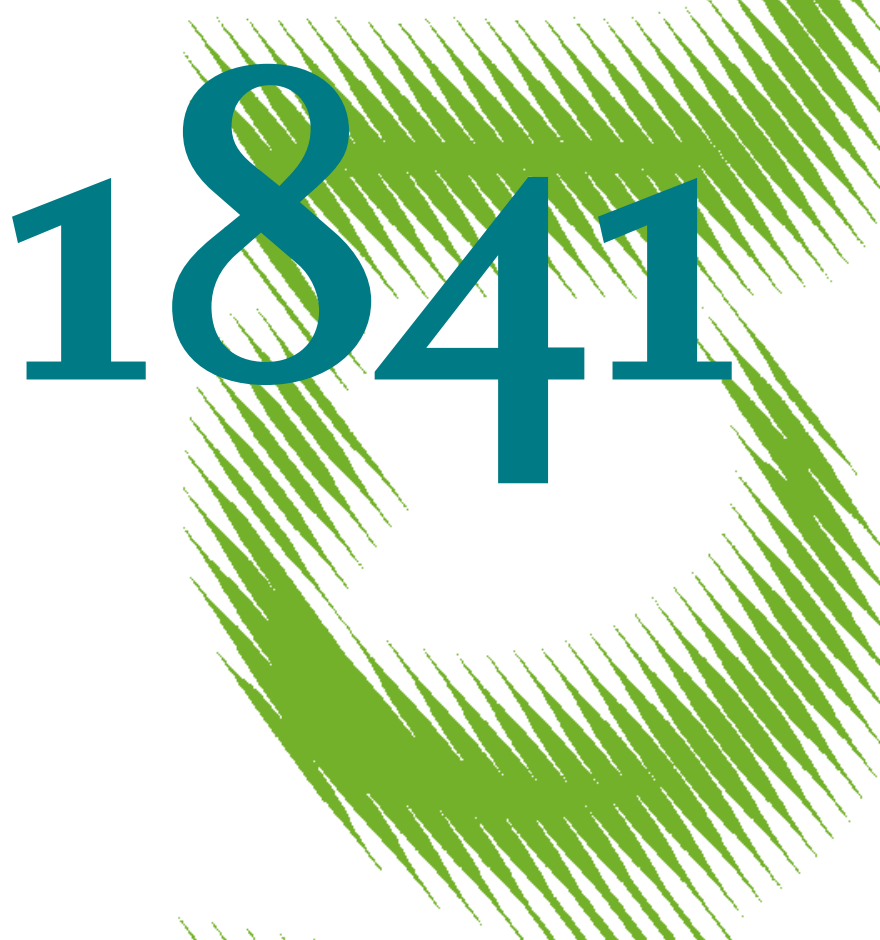

Is Monetary Policy Gender Neutral? Evidence from the Stock Market 
Opinions expressed in this paper are those of the author(s) and do not necessarily reflect views of the institute.

IMPRESSUM

(C) DIW Berlin, 2020

DIW Berlin

German Institute for Economic Research

Mohrenstr. 58

10117 Berlin

Tel. +49 (30) $89789-0$

Fax +49 (30) $89789-200$

http://www.diw.de

ISSN electronic edition 1619-4535

Papers can be downloaded free of charge from the DIW Berlin website:

http://www.diw.de/discussionpapers

Discussion Papers of DIW Berlin are indexed in RePEc and SSRN:

http://ideas.repec.org/s/diw/diwwpp.html

http://www.ssrn.com/link/DIW-Berlin-German-Inst-Econ-Res.html 


\title{
Is Monetary Policy Gender Neutral? Evidence from the Stock Market*
}

\author{
Caterina Forti Grazzini ${ }^{\dagger}$ \\ CHI HYun KIM
}

January 10, 2020

\begin{abstract}
We use US household survey data from 2001-2017 to investigate whether monetary policy has heterogeneous effects on women's and men's financial portfolio decisions by analyzing their equity investment. On the one hand, monetary policy significantly affects the entry decisions of women, but not of men: after a contractionary shock, the probability of women entering the stock market decreases. On the other hand, monetary policy is gender-neutral for stock market participants: there are no significant differences in exit or in portfolio rebalancing decisions between women and men. Our results suggest that monetary policy does not have a heterogeneous effect on portfolio decisions across genders once women participate in the stock market.
\end{abstract}

JEL-Classification: E58, J16, G11.

Keywords: Monetary Policy, Gender, Stock Market Participation, Portfolio Choices.

${ }^{*}$ We thank Franciska Bremus, Marco del Negro, Alexander Kriwoluzky, Dieter Nautz, seminar participants at the 2019 Time Series Workshop in Tornow and at the 20th IWH-CIREQ-GW Macroeconometric Workshop in Halle. This paper should not be reported as representing the views of the European Central Bank (ECB). The views expressed are those of the authors and do not necessarily reflect those of the ECB.

${ }^{\dagger}$ European Central Bank, caterina.forti_grazzini@ecb.europa.eu, sites.google.com/view/caterinafortigrazzini.

${ }^{\ddagger}$ Free University Berlin and DIW Berlin, ckim@diw.de, sites.google.com/site/chihyunkimecon/. 


\section{Introduction}

The primary mandate of major central banks is to maintain price stability, which is the reason why central bankers have payed less attention to the distributional impact of their policy measures on inequality. However, in the aftermath of the Global Financial Crisis of 2008, economic inequality in industrialized countries increased drastically and the public raised concerns that the long-enduring low interest rate environment was exacerbating to this problem, since low interest rates only benefit a few groups of households with certain characteristics.

One important aspect of this inequality debate is gender. Insights of feminist economists show how traditional monetary policy, in combination with finance-dominated capitalism, may favor men at the expense of women (Bakker, 1994; Van Staveren, 2014a,b; Young, 2018). For instance, men invest significantly more in financial assets than women. This gender-specific difference in investment behavior can be explained through women's higher risk aversion (Jianakoplos and Bernasek, 1998; Sunden and Surette, 1998; Jianakoplos and Bernasek, 1998), lack of confidence (Barber and Odean, 2001; Croson and Gneezy, 2009), and a wider range of responses to economic uncertainty (Fisher and Yao, 2017). In a prolonged period of low interest rates - and, thus, high asset prices - the low female propensity to invest in financial assets may lead to a distributional divergence of financial wealth between women and men, thus increasing the gender wealth gap.

In this paper, we investigate an additional channel - through which monetary policy can affect the gender wealth gap other than the valuation effect of financial portfolios for women and men. Namely, monetary policy can influence the investment decisions of women and men by affecting their risk-taking behavior. We address our research question by focusing on the investment behavior of US households in the stock market. We use survey data from the Panel Study of Income Dynamics (PSID) between 2001 and 2017. The choice to focus on US households is twofold. First, the PSID data set is a rich source of dis-aggregated and detailed information on households' portfolio composition, wealth, and demographics. Second, compared to other countries, US households' investment decisions are crucial for their retirement. The lower propensity of women to invest in risky assets like stocks could translate into large differences in the accumulation of financial wealth for retirement. Thus, understanding how monetary policy may influence women's retirement wealth is crucial.

As a first step, we investigate the effect of monetary policy on households' stock market participation, focusing on the binary entry- and exit decisions of women and men separately. Our results show that only entry decisions of women are affected by monetary policy. After a contractionary monetary policy shock, single female-headed households are $11 \%$ less likely to enter the stock market. Men's entry decisions and the exit decisions of both gender are not affected by monetary policy. This result is interesting since we observe gender-specific effects on entry decisions, which are made by stock market non-participants, while exit decisions, which are made by stock market participants, are not affected by monetary policy. This result is in 
line with the findings in the literature that female non-participants are more risk averse than male (both participants and non-participants) and female stock market participants. These female non-participants react more strongly to economic events that negatively affect their wealth (Jianakoplos and Bernasek, 1998; Barber and Odean, 2001; Fisher and Yao, 2017). In order to visualize the economic numbers of this effect, we conduct an exercise to simulate the missed out capital gains of single women through monetary policy.

As a second step, we concentrate on stock market participants, analyzing how women and men adjust their financial portfolio after a monetary policy shock. This additional analysis at the intensive margin (i.e., only considering participating households) shows that monetary policy is gender-neutral for stock market participants: even though the average household adjusts their portfolio in a manner that is consistent with the risk-taking channel of monetary policy transmission mechanism, we find no significant differences across genders. ${ }^{1}$

Two empirical issues are worth mentioning. First, in the PSID, the term "household head" refers to the husband in a heterosexual married couple, such that we cannot identify whether the husband or spouse (or both) is making the financial decisions. Nevertheless, the financially responsible person of single-headed households is clear. Therefore, we compare the investment behavior of single female-headed households with (i) married households and (ii) single maleheaded households. This comparison may not be perfect to identify the investment behavior of all women, but it still provides meaningful and interesting insights. For instance, the group "single female-headed households" is highly exposed to poverty not only compared to men, but also to their married peers (Cawthorne, 2008). This shows that the marital status of individuals can also play an important role in their investment decisions (e.g. Sunden and Surette, 1998). Therefore, it is important to understand how the poorest group in society responds to monetary policy compared to other groups, especially given the fact that divorce rates are high in most industrialized countries.

The second empirical challenge lies on the identification of US monetary policy shocks. We identify monetary policy shocks of the Federal Reserve (Fed) at a daily frequency following the method proposed by Nakamura and Steinsson (2018). With this method, we capture exogenous variations in interest rate futures within a narrow time window around FOMC meetings. Subsequently, in order to match the frequency of the household survey data, we aggregate the daily monetary policy shocks into a series with biennial frequency. In doing so, we take into account the month of the year in which each household answers the survey questions, thus allowing us to construct an idiosyncratic biennial monetary policy shock series for each household. Afterwards, we improve our identification by exploiting households' heterogeneity in financial wealth and gender, which influences their exposure to monetary policy shocks.

Our study contributes to the growing literature that uses micro-level data on the composition

\footnotetext{
${ }^{1}$ According to the risk-taking channel of monetary policy, after a contractionary monetary policy shock, investors adjust their portfolio by selling riskier assets and purchasing safer options.
} 
of households' wealth and income to estimate the heterogeneous effects of monetary policy on wealth inequality. The idea is that monetary policy interventions have distributional effects across the population depending on individuals' demographic characteristics and their composition of assets and liabilities. Bivens (2015), Domanski et al. (2016), Lenza and Slacalek (2018), and Ampudia et al. (2018) focus on unconventional monetary policy tools and conduct empirical reduced-form simulation exercises. They quantify the distributional effects of monetary policy through the valuation of asset prices by examining households' financial portfolio structure. They show that unconventional monetary policy disproportionately benefits households at the top wealth distribution. The same result is reached by Adam and Tzamourani (2016) in the context of conventional monetary policy. In addition, a new strand of literature investigates the effect of interest rate changes on the active risk-taking behavior of private investors, finding that investors' risk appetite increases if monetary policy is loosened (Lian et al., 2018; Daniel et al., 2018). Our analysis provides new insights to this literature by examining gender as an additional source of household heterogeneity that might interact with monetary policy. Young (2018) is the first to formulate potential mechanisms through which unconventional monetary policies can affect gender wealth inequality. However, the study only provides descriptive results. Our study complements her arguments by providing a structural analysis.

We also contribute to the literature investigating whether macro/financial events affect portfolio decisions by affecting households' risk-aversion. In their seminal paper, Malmendier and Nagel (2011), using US household survey data, show that personal past experiences can shape the current investment decisions of households. In particular, investors who experienced periods of abnormally low returns are less likely to invest in risky assets today. Similar results are obtained by Ampudia et al. (2018) for the euro area. Few papers consider the relationship between financial fluctuations and portfolio adjustments in the context of the 2007-2009 financial crisis. Bucher-Koenen and Ziegelmeyer (2013) find that crisis episodes have a negative impact on household's participation in the financial markets in both the short- and long-run. Guiso et al. (2018) show that, after the drop in stock prices in the aftermath of the Global Financial Crisis, Italian investors re-adjusted their investment in stocks in a direction (and magnitude) consistent with a sharp increase in their risk aversion. Contrary to these studies, we do not focus on how specific events affect financial markets, but rather examine whether women and men respond in a different way to monetary policy in general.

The remainder of the paper is structured as follows. Section 2 describes the data and the construction of our final data set. Section 3 discusses the identification of monetary policy, the empirical framework, and the results. In section 4 , we provide a simulation study to calculate the impact of our results on the capital gains/losses of women through monetary policy. Section 5 concludes. 


\section{Data}

\subsection{The Panel Study of Income Dynamics}

We use Panel Study of Income Dynamics (PSID) survey data, which is a nationally representative longitudinal study of US families. In the PSID, the unit of observation is a household, which is defined as a group of people living together as a family. Besides a broad range of socio-economic variables - such as gender, age, marital status, number of children etc. - the PSID also provides rich information on the households' financial wealth and portfolio composition.

With respect to financial portfolio volume and composition, households are asked to report information on their holdings of three broad asset classes: (i) stocks (shares of stock in publicly held corporations, mutual funds, and investment trusts); (ii) riskless assets (checking and savings accounts, money market funds, certificates of deposits, savings bonds, treasury bills); and (iii) other assets (bond funds, cash value in a life insurance policy, a valuable collection for investment purposes, or rights in a trust or estate). For stocks, the PSID additionally asks the households about their purchases or sales. For the riskless asset class, the PSID assumes that riskless assets bear no return, such that the value change of this asset class is purely driven by the net purchase. Note that for our analysis, we do not include any asset held in employer-based pensions or IRAs. ${ }^{2}$

For our analysis, we include survey waves from 2001 to 2017. The survey is of biennial frequency. The sample size of each wave ranges over 5000 to 7000 , but the size or our final data set is significantly reduced due to the data requirements that we impose. In order to capture the different effect of monetary policy across genders, we analyze the investment decisions of single-headed female households in contrast to male-headed households. ${ }^{3}$

\subsubsection{Construction of the relevant variables}

In order to analyze how monetary policy affects the investment choices of women and men, we first examine their dynamic decisions to own stocks or not. For this, we construct two binary variables, Entry $y_{i, t}$ and Exit $t_{i, t}$, that visualize the entry- and exit decisions of households in the stock market. Entry $y_{i, t}$ equals one if household $i$ does not participate in the stock market at $t-1$, but participate at $t$, and zero if it does not participate in both waves. Exit $t_{i, t}$ is equal to one if household $i$ owns stocks in $t-1$, but does not in $t$, and zero if the household participates in the stock market in both waves.

In the second part of the analysis, we concentrate on household's stock market investment choices, conditioning on participation. Here we consider only households that have positive investment in stocks in both $t-1$ and $t$. In order to visualize how they adjust their stock

\footnotetext{
${ }^{2}$ We exclude investments in retirement accounts because there is little trading in these accounts (Ameriks and Zeldes, 2004). Furthermore, the liquidity and payoff properties of retirement accounts are different from direct stock ownership (Haliassos and Bertaut, 1995).

${ }^{3}$ See Section 2.1.2 for a more detail discussion on how to disentangle women and men portfolio choices when using household data.
} 
investment after a monetary policy shock, we calculate their active saving of stocks, which is defined as the sum of all stocks sold or/and purchased between $t-1$ and $t$. In addition, we also calculate the active saving of riskless assets. ${ }^{4}$ The joint analysis of how monetary policy affects the active saving of stocks and riskless assets captures how households actively adjust their financial risk by rebalancing their financial portfolio. ${ }^{5}$

\subsubsection{How to disentangle women and men in the PSID data}

In order to analyze the investment behavior of women and men separately, we need to identify the person who is responsible for each respective household's financial decisions. In many household surveys, this is the household head, who is defined as the financially knowledgeable (and responsible) person of the household unit. However, in the PSID the term household head refers to the husband in a heterosexual married couple and to an adult of either sex in single-headed households. Therefore, the household head is always a male person in case of a married couple, irrelevant of whether he makes the financial decisions for the family unit or not. However, there are some cases where the head of a married couple can be female. For example, this is the case if the husband does not grant the interview or if the husband is in jail. Therefore, for married family units it is not trivial to know who is in charge of financial decisions.

The optimal strategy to overcome this problem would be to compare single female- and male-headed households. Unfortunately, this is not possible due to the very low number of observations that we have when we pool single men and women together. Therefore, we proceed in the following manner. To identify investment behavior of women, we use only data on single female-headed households. In our sample, we have a total of 2105 households. Thereafter, we compare their investment behavior with male-headed households of both marital status (single and married).We assume that the investment decisions of the latter group is always influenced by the investment behavior of men. For this group, we have a total of 12673 households in our sample.

Our definitions of women and men are chosen for two principle reasons. First, even if we were able to identify the financially responsible person in a married couple, we still cannot rule out the possibility that married couples tend to make joint investment decisions (Sunden and Surette, 1998; Barber and Odean, 2001; Agnew et al., 2003). Second, understanding the investment behavior of single women is crucial since they represent the poorest group in the US economy (Semega et al., 2019). If single women react differently to monetary policy shocks than other groups with higher income and wealth, the wealth gap between the two groups will widen.

Nevertheless, we are aware of the fact that pooling single and married male-headed households

\footnotetext{
${ }^{4}$ We assume that riskless asset bear no return, therefore we classify any change in value between waves $t$ and $t-1$ as active saving.

${ }^{5}$ We do not assume that the asset class other assets bears no returns. However, since we do not have information on the purchases or sales of this asset class, we are not able to calculate the active saving.
} 
can be problematic since marital status can play a significant role in investment decisions of individuals. If married male-headed households react differently to monetary policy compared to single male-headed households, then we might not be able to properly disentangle female and male reaction to monetary changes. Therefore, we test whether investment decisions of single male-headed households differ significantly from married male-headed households. ${ }^{6}$ For simplicity, throughout the paper we use the term "woman" to indicate a single female-headed household, and "man" to capture a male-headed household.

\subsubsection{Sample selection}

We include only households that participate in the survey for at least three consecutive waves. ${ }^{7}$ Moreover, we exclude households where the age of the head is younger than 25 years or older than 65 years. Also, we only include households where the marital status of the head does not change throughout the sample. We also control for possible mismatches in the reported answers and eliminate households that do not report consistent data. In particular, we discard households that (i) declare not to have stocks, but then report a positive value of stock wealth; (ii) indicate a negative value of stock wealth; and (iii) declare a non-zero active saving, but at the same time report zero purchases or sales of assets. Moreover, we trim all wealth variables at the $1 \%$ level to mitigate the impact of outliers. Finally, we use sample weights provided by PSID when producing the summary statistics, but we do not weight observations in the regression analysis, as it would be inefficient (Deaton, 1997). ${ }^{8}$

\subsection{Summary statistics}

Table 1 provides some household-level summary statistics of our final data set, pooling all waves. Panel $A$ reports the statistics for all households that satisfy all minimum requirements to be included in the analysis (the full sample). Panel $B$ shows the statistics of the stock market participants in our final data set (that is, households that have at least $1 \$$ invested in stocks in wave $t-1$ and in $t$ ). We compare single female-headed households versus households that are composed by one or more family units where the head is a man. Summary statistics are calculated using sample weights provided by the PSID. ${ }^{9}$

\footnotetext{
${ }^{6}$ We also compare single female-headed households with only married male-headed households and show that the results do not differ compared to our analysis with male-headed households of both marital status.

${ }^{7}$ This choice is driven by the large number of households appearing in the PSID for only one wave. Moreover, in the robustness check section in the appendix, we relax this constraint and show that results do not change.

${ }^{8}$ In particular, there are two sets of explanations for the choice of not using sample weights in this context. First, as we control for outliers and trim the data set at the cross section, we reduce the representativeness of the weighted data. The second issue arises from the usage of panel data. When applying fixed effect estimation, it is not possible to assign different weights over time for the same family unit. This would dramatically reduce the accuracy of the weighted data in representing the target population.

${ }^{9}$ In particular, each household is weighted using the sample weight provided by the PSID for the first wave the household appears in our data set. For an overview of the unweighted summary statistics, please see Table 6 in the appendix.
} 
With regard to all households of our sample (Panel $A$ ), on average, $29 \%$ of the male-headed households participate in the stock market during 2001-2017. In contrast, only $16 \%$ of single female-headed households invest in the stock market. In addition, female-headed households seem to display higher risk aversion, as the rate of stock market entry is lower than their male counterpart. On average, the value of man's financial portfolio sum up to more than $\$ 100,000$, which is 3 times higher than woman's. Moreover, stock holdings of male-headed households are about 4 times higher than woman's. This implies that men prefer riskier financial investments (with a $17 \%$ of their portfolio invested in risky assets, compared to the female $9 \%$ ). Thus, women appear to hold less wealth and they invest a lower percentage of their net worth and financial portfolio in risky assets. These statistics are in line with the literature that documents that women are more risk averse (and thus cautious) in their investment behavior. However, the picture is slightly different when considering participating households. Although women still invest a lower share of their net worth in risky assets, the financial gap partially closes, with the composition of the financial portfolio being the same across genders (roughly $60 \%$ invested in risky assets). Thus, at least for stock market participants, we cannot support the hypothesis of higher female risk aversion in investment decisions compared to men.

Our descriptive analysis shows that stock market participants tend to be wealthier with higher financial wealth and with higher education level. Moreover, participants invest a higher share of their financial portfolio in stocks. However, home ownership and employment are comparable. When taking a closer look, however, we see that the net worth ratio between women in the participating and full sample groups is roughly 5 , while than of men is around 2.3 , suggesting that women might require more wealth (with respect to men) to bear the risk to invest in risky assets and that women are, in turn, more risk averse than men. The female and male ratio between stock holding in Panel $A$ and $B$ (7.6 and 4.4, respectively) points in the same direction.

\section{Empirical analysis}

\subsection{Identification of monetary policy shocks}

In order to identify the effects of monetary policy on investment behavior of women and men, it is crucial to obtain an exogenous measure of monetary policy shocks. In this paper, we proceed in the following way. We identify monetary policy shocks using the high frequency identification (HFI). Using high-frequency financial data, this method enables us to identify exogenous policy changes that are not anticipated by financial market participants. As a next step, we use information on household-specific characteristics to identify how strongly households are exposed to such monetary policy shocks.

In particular, we exploit three layers of household heterogeneity. First, households are not interviewed in the same month, such that they can be exposed to different monetary policy shocks 
Table 1: Summary statistics

\begin{tabular}{|c|c|c|c|c|c|c|}
\hline & Mean & $\mathrm{SD}$ & Mean & $\mathrm{SD}$ & Mean & $\mathrm{SD}$ \\
\hline & \multicolumn{2}{|c|}{ All households } & \multicolumn{2}{|c|}{ Women } & \multicolumn{2}{|c|}{ Men } \\
\hline \multicolumn{7}{|l|}{ Panel A: Full sample } \\
\hline Stock market exit & 0.30 & 0.46 & 0.34 & 0.47 & 0.30 & 0.46 \\
\hline Stock market entry & 0.10 & 0.30 & 0.06 & 0.24 & 0.11 & 0.31 \\
\hline Stock market part. & 0.27 & 0.44 & 0.16 & 0.37 & 0.29 & 0.45 \\
\hline Stock holding & 55056.19 & 627113.15 & 14580.03 & 106326.21 & 63486.96 & 687198.74 \\
\hline Riskless holding & 27205.67 & 90301.63 & 13009.60 & 30310.10 & 30128.64 & 98018.67 \\
\hline Stock active holding & 235668.44 & 12375997.76 & 67.43 & 2235.77 & 284996.11 & 13609611.55 \\
\hline Riskless active saving & 5882.27 & 88949.70 & 2403.31 & 29122.42 & 6595.02 & 96837.34 \\
\hline Stock share & 0.15 & 0.30 & 0.09 & 0.24 & 0.17 & 0.31 \\
\hline$\Delta$ Stock share & -0.01 & 0.28 & -0.00 & 0.23 & -0.01 & 0.29 \\
\hline Financial wealth & 96771.38 & 702582.00 & 35212.30 & 166566.79 & 109567.22 & 767798.25 \\
\hline Net worth & 365631.10 & 1333478.63 & 218791.56 & 1550873.64 & 396103.14 & 1283039.44 \\
\hline Income & 92487.03 & 123296.94 & 46927.72 & 39714.12 & 101881.37 & 132306.03 \\
\hline Home ownership & 0.84 & 0.37 & 0.68 & 0.46 & 0.87 & 0.33 \\
\hline College degree & 0.47 & 0.50 & 0.47 & 0.50 & 0.48 & 0.50 \\
\hline Employed & 0.89 & 0.31 & 0.86 & 0.35 & 0.90 & 0.30 \\
\hline Observations & 14807 & & 2105 & & 12673 & \\
\hline
\end{tabular}

Panel B: Stock market participants

\begin{tabular}{lcccccc} 
Stock holding & 253891.93 & 1404329.77 & 113215.46 & 299449.61 & 269248.76 & 1474872.99 \\
Riskless holding & 57592.73 & 157731.34 & 36930.01 & 59835.86 & 59849.30 & 164785.85 \\
Stock active saving & 3387.74 & 30543.59 & 114.58 & 6042.69 & 3749.08 & 32103.14 \\
Riskless active saving & 12960.12 & 157328.94 & 7205.88 & 53615.60 & 13588.52 & 164736.41 \\
Stock share & 0.60 & 0.29 & 0.58 & 0.30 & 0.60 & 0.29 \\
$\Delta$ Stock share & 0.00 & 0.29 & -0.02 & 0.29 & 0.00 & 0.30 \\
Financial wealth & 342547.85 & 1548857.51 & 175188.84 & 421582.63 & 360820.18 & 1624224.00 \\
Net worth & 878261.14 & 2234640.50 & 1090033.29 & 4460878.19 & 855101.66 & 1834792.98 \\
Income & 141347.15 & 203069.50 & 68378.32 & 84711.07 & 149304.05 & 210512.67 \\
Home ownership & 0.93 & 0.25 & 0.86 & 0.35 & 0.94 & 0.24 \\
College degree & 0.69 & 0.46 & 0.74 & 0.44 & 0.69 & 0.46 \\
Employed & 0.90 & 0.30 & 0.85 & 0.35 & 0.91 & 0.29 \\
\hline Observations & 2482 & \multicolumn{5}{c}{2314} \\
\hline
\end{tabular}

Note: The table shows the summary statistics of the relevant wealth and income variables included in the analysis. Panel $A$ presents the results for the full sample; Panel $B$ for the sub-sample of stock market participants (at least $\$ 1$ invested in stock in both $t-1$ and $t$ ). The sample period is 2001-2017. Household's observations are weighted by the longitudinal weights provided by the PSID. Source: PSID 
within a certain wave. Second, we use household's financial characteristics (and in particular, their investment in stocks and total financial portfolio) to assess their exposure to monetary policy. Finally, we account for the household head's gender. In this way, we can compare the behavior of households that are expected to be more or less affected by monetary policy due to a different composition of their financial portfolio and/or gender.

\subsubsection{The high frequency identification}

The high frequency identification method employs high frequency data on interest rate futures to identify the surprise component of monetary policy announcements. To derive the shock measure, changes in these futures are measured in a narrow time window around the FOMC meetings. If all publicly available information is already incorporated into the financial markets at the beginning of the time window, fluctuations in the interest rate futures around the FOMC announcement are only driven by the unexpected component of the monetary policy announcement itself. In order to ensure the exogeneity of the shock measure, it is crucial that the time span around the FOMC meeting is short enough. ${ }^{10}$

We adapt the method of Nakamura and Steinsson (2018) and construct monetary policy shocks as the first principle component of the daily change in five interest rate futures. These include federal funds futures (the current-month contract rate and the contract rates for each of the next three months) and Eurodollar futures (at two to four quarters in the future). Borrowing their terminology, we refer to the identified shocks as "monetary policy news shocks." For convenience, we scale the shocks such that their effect on the 1-year nominal Treasury is 100 basis points. ${ }^{11}$. We use daily data from January 1, 2001, to December 31, 2017, and we include all FOMC scheduled meetings that happened throughout this 17 year period. Figure 1 depicts the time series of the policy news shock.

\subsubsection{Household-specific information set}

After identifying daily monetary policy shocks, we need to aggregate them into biennial frequency to match the frequency of the household survey data. The simplest option would be to aggregate the monetary policy shocks over 24 months (from January of wave $t-1$ to December of wave $t$ ). However, by doing so, we would neglect the fact that households are not interviewed in the same month and, thus, that their answers regarding the financial variables refer to different periods. Indeed, as can be seen in Figure 5 in the appendix, the interview dates are dispersed throughout all months of an interview year (with the exclusion of January and February).

Why should the difference in the interview dates matter for our analysis? Consider two households $(A$ and $B$ ) that have been interviewed during the years 2001 and 2003. Suppose

\footnotetext{
${ }^{10}$ For a detailed description of the method, see Appendix C.

${ }^{11}$ For a more detailed description of the method of Nakamura and Steinsson (2018), see Appendix C
} 
Figure 1: The policy news shocks, $2001-2017$

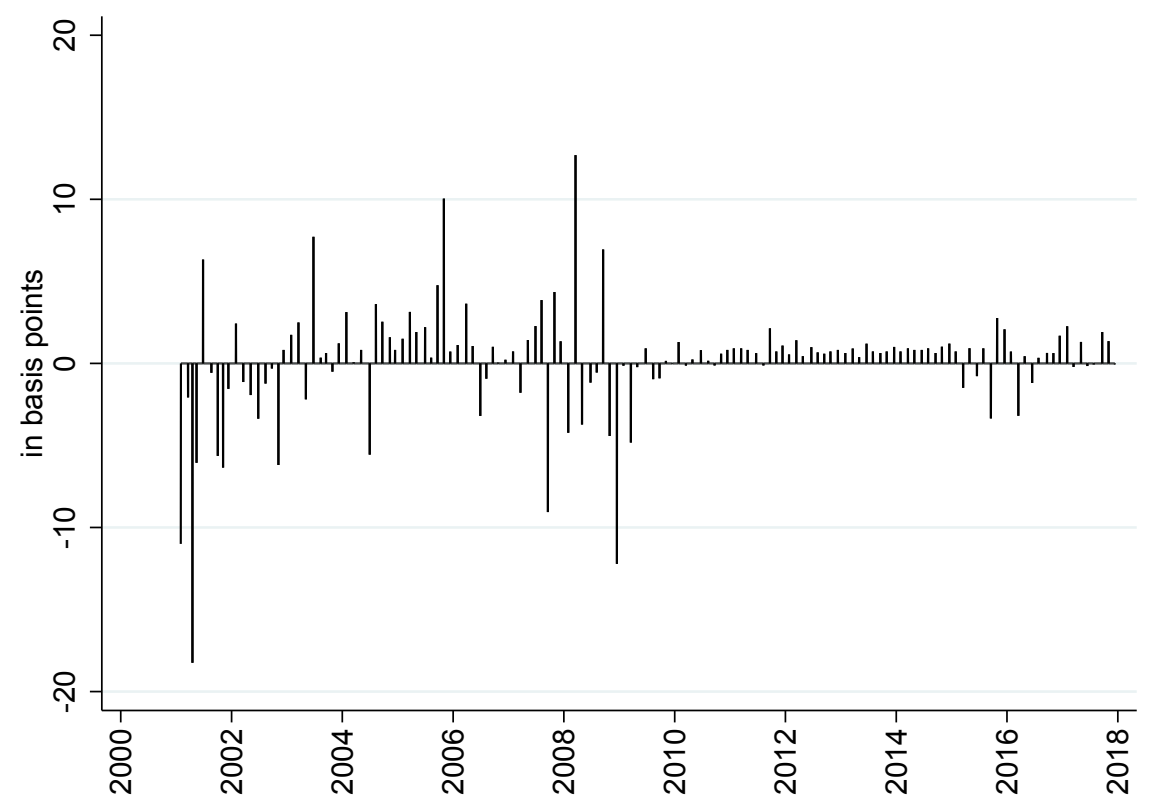

Note: The monetary news shocks estimated at the daily frequency over the period $2001-2017$. We scale the policy news shock such that it has a 100 b.p. effect on the 1-year Treasury.

that in the year 2001, both households are interviewed in March, while in 2003, household $A$ is interviewed in March while household $B$ in May. Figure 2 provides a graphical presentation of the monetary policy shock information set that the two households experienced between the two surveys. Here we can clearly see that household $A$ experienced fewer FOMC meetings than household $B$ and, thus, is possibly exposed to fewer monetary policy shocks. Therefore, if we would aggregate the monetary policy news shocks from January 2011 to December 2013 and then evaluate its effects on the investment behavior of both households, then we would obtain biased results. This can be especially problematic if, referring again to the example in Figure 2, there is a major monetary policy shock between March 2003 and May 2003.

Figure 2: Survey dates and monetary policy events

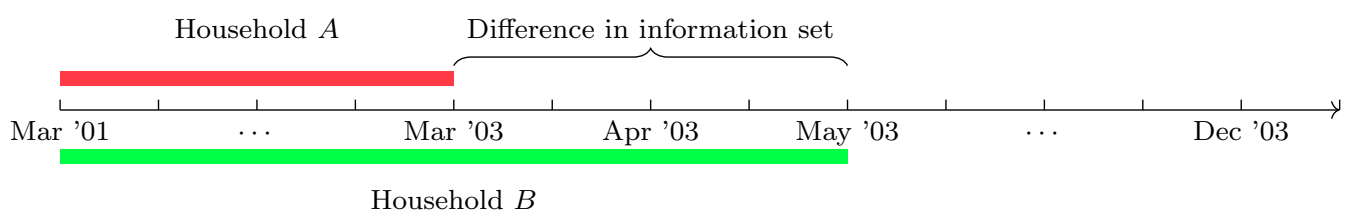

Note: The figure shows how answering survey questions in different months implies that, for example, households A and B are subject to different monetary policy shocks between waves $t-1$ and $t$.

Therefore, we construct a household-specific monetary policy news shock series that takes 
into account households' different information set by summing up the monetary policy shocks for each household and taking into account their interview dates,

$$
M P_{i, t}=\sum_{j=I_{i, t-1}}^{T_{i, t}} m p s_{j}
$$

where $M P_{i, t}$ is the biennial monetary policy news shock series for household $i$ in wave $t$; $I_{i, t-1}$ and $I_{i, t}$ are the day of household $i$ 's interview in wave $t-1$ and $t$, respectively. $m p s_{j}$ is the daily monetary policy news shock on day $j$. Table 2 compares the summary statistics of the daily monetary policy news shock with the average biennial household-specific series over the empirical analysis period (2001-2017). Figure 3 depicts two monetary shock series that are representative for households $A$ and $B$ of our previous example.

Figure 3: Biennial household-specific monetary policy news shock, 2003-2017

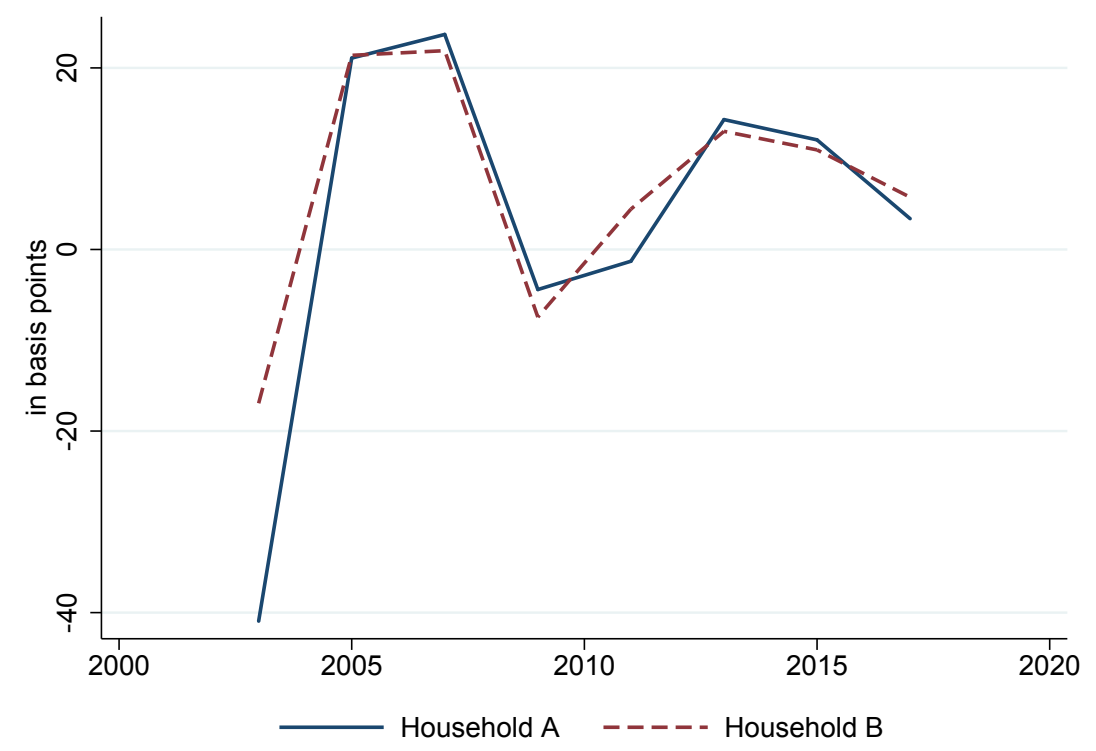

Note: The two lines are obtained by estimating a household-specific monetary policy shock series at the daily frequency (5). Afterwards, we aggregate the monetary policy shocks into a biennial series, depending on the household's interview month.

\subsubsection{Households' heterogeneous exposure to monetary policy}

The effect of monetary policy on household investment behavior can vary across households due to their heterogeneous characteristics. The first source that we take into account is financial wealth. The intuition is that one of the mechanisms, through which monetary policy can affect household investment decisions, is through valuation effects: monetary policy affects yields and prices of assets and, thus, changes the value of households' financial portfolios. Therefore, it is 
Table 2: Summary statistics of the monetary policy shocks, 2001-2017

\begin{tabular}{lcc}
\hline \hline & $\begin{array}{c}\text { High-frequency monetary } \\
\text { news shock }\end{array}$ & $\begin{array}{c}\text { Biennial household-specific } \\
\text { monetary news shock }\end{array}$ \\
\hline Mean & 0.001 & 0.039 \\
Median & 0.007 & 0.080 \\
Std. Dev. & 0.034 & 0.177 \\
Min & -0.182 & -0.433 \\
Max & 0.127 & 0.306 \\
\hline \hline
\end{tabular}

Note: Summary statistics of monetary shocks over the period $2001-$ 2017. The shocks are all scaled to have a one-unit impact on the 1-year German Treasury bond yields. The aggregated biennial household-specific monetary news shock are based on summing the shocks within a two year period and taking into account the interview dates of each household.

plausible to claim that the more financial wealth a household holds, the more it is affected by monetary policy shocks. Based on these insights, we interact our household-specific aggregated monetary policy shocks with the household's lagged financial wealth $\left(W_{i, t-1}\right)$, which we define as the exposure variable:

$$
M P_{i, t}^{*}=M P_{i, t} \times W_{i, t-1},
$$

where $M P_{i, t}$ is the household-specific biennial monetary policy news shock series. $W_{i, t-1}$ can be, depending on the empirical exercise we perform, either the lagged total financial portfolio or the stock holding. The variable $M P_{i, t}^{*}$ has a straightforward interpretation: It captures how much household $i$, at time $t$, is affected by monetary policy shocks that occurred between $t-1$ and $t$ due to its financial wealth in $t-1$. Thus, using $M P_{i, t}^{*}$ we can analyze how an exogenous change in financial wealth due to a monetary policy shock passes through to households' stock investment choices.

Finally, we also interact our monetary policy shock variable with a dummy variable that visualizes different households with regard to the gender of the household head. The main dummy variable we use is $W_{o m a n}$, which takes the value one if the household's head is female and single and zero if the head is male. In this way, we are able to capture the possible gender-specific effects of monetary policy.

$$
M P_{i, t}^{*} \times \text { Woman }_{i}=M P_{i, t_{i}} \times W_{i, t-1} \times \text { Woman }_{i} .
$$

Furthermore, note that we also interact the monetary policy shock variable with other dummy variables that distinguishes between (i) single female-headed households and married male-headed households; and (ii) married male-headed households and single male-headed households. We do 
this in order to confirm the robustness of our results.

\subsection{Results}

In this section, we present our econometric framework and results. First, we examine the effect of monetary policy on the change in stock market participation status of women and men (entry and exit). Thereafter, we focus exclusively on stock market participants (i.e., having positive investment in stocks for at least two consecutive waves) and analyze the effect of monetary policy on their trading activity.

\subsubsection{Entry and exit decisions}

We start by investigating how changes in monetary policy stance affects the stock market participation status of households. For this purpose, we consider two dummies, Exit $t_{i, t}$ and Entryi,t (see Section 2.1.1 for a detailed description of their construction).

We employ the following probit model,

$$
\begin{aligned}
& y_{i, t}^{*}=\delta_{t}+\delta_{r}+\alpha X_{i, t-1}+\beta_{1} M P_{i, t}+\beta_{2} M P_{i, t} \times \text { Woman }_{i}+\beta_{3} M P_{i, t}^{*}+ \\
& \quad \beta_{4}\left(M P_{i, t}^{*} \times \operatorname{Woman}_{i}\right)+\beta_{5}\left(W_{i, t-1} \times \operatorname{Woman}_{i}\right)+\beta_{6} W_{i, t-1}+\beta_{7} \operatorname{Woman}_{i}+u_{i, t}, \\
& y_{i, t}=1\left[y_{i, t}^{*}>0\right]
\end{aligned}
$$

where $y_{i, t}$ can be either Exit $t_{i, t}$ or Entry $y_{i, t} . X_{i, t}$ is a vector of control variables that includes household financial characteristics (lagged net worth and family income, change in net worth and family income, total inheritance, dummy for the first mortgage, dummy for the second mortgage), and demographic characteristics (the number of children, the age of the head, the head's age squared, marital status, completed college education, working in the finance industry, total number of family components, home ownership). We also include time- and region of residency- fixed effects $\left(\delta_{t}\right.$ and $\left.\delta_{r}\right)$. Woman $i$ is a dummy variable equal to 1 if the household is single-headed and female, zero if it is male. $W_{i, t-1}$ is the previous year total financial portfolio. The remaining terms in Equation 4 are the triple interaction term constructed in section 3.1.3 and all other mean and double interaction effects that should be included when employing a three-way interaction term. Thus, with our empirical model we are able to capture the mean effect of monetary policy (coefficient $\beta_{1}$ ) and how the mean effect changes if households are women (coefficient $\beta_{2}$ ), if they are exposed to monetary policy (coefficient $\beta_{3}$ ) and if they are exposed and women (coefficient $\beta_{4}$ ). $u_{i, t}$ is the error term.

Table 3 presents the results of the probit models on the 2001-2017 sample, which we estimate with maximum-likelihood. We report the marginal effects, interpreted as the effect of monetary policy on the probabilities (of entering or exiting the stock market) evaluated at the sample mean of the explanatory variables. We only show the estimates of the parameters of interest. 
Standard errors (in parenthesis) are clustered at the household level. In this set of results, single women are opposed to households composed by one or more individuals where the head is a man.

Results show that there is a negative effect of being a single woman on stock market entrance (Column (2)): Women are 3.4\% less likely to enter the stock market than men. These results are in line with the literature, which documents a high non-participation rate of women in the financial markets (Sunden and Surette, 1998; Barber and Odean, 2001; Dwyer et al., 2002; Agnew et al., 2003). Compared to this, gender does not seem to determine the stock market exit probability.

We now turn to the effects of monetary policy. Our analysis shows that a contractionary monetary policy shock that increases the one-year Treasury bond yields by 100 basis points has a negative and highly significant effect on female probability of stock market entry (Column (2)), as women's likelihood of entering the stock market decrease by $11 \%$. However, the marginal effect for men is insignificant. Compared to this, monetary policy does not seem to affect men and women's exit decision at all (Column (1)). To check the sensitivity of the results to the sample choice, we also conduct the same analysis for two additional sub-samples. First, we examine whether single men and married male-headed households respond to monetary policy in a significantly different manner. If this is the case, the results of our baseline model will be distorted since we are pooling these two groups together. Second, we also compare single women and male-headed households. Our sensitivity exercise confirms the credibility of our baseline results (see Table 10 and 11 in the appendix).

In summary, we show that gender can play a role in how monetary policy affects stock market participation of households. In particular, monetary policy seems to affect entry decisions of women, while men remain unaffected. However, we do not observe any structural differences in the way how monetary policy affects exit decisions of women and men. This is interesting since exit decisions are made by stock market participants, where demographic and economic differences between women and men decrease compared to non-participants.

\subsubsection{Monetary policy and active saving}

In this section, we focus exclusively on stock market participants and examine how households adjust their financial portfolio following a monetary policy shock. According to the risk-taking channel of monetary policy, as documented by Lian et al. (2018), Daniel et al. (2018), a contractionary monetary policy shock will induce households to sell risky assets, like stocks, and to purchase safer options, like Treasury bonds.

In order to capture the pure rebalancing behavior of households, it is crucial to distinguish between active and passive savings of assets. In general, the value of any financial investment can change between waves $t-1$ and $t$ for two reasons. Either households sell or buy assets (active 
Table 3: Monetary policy and change in stock market participation, marginal effects

\begin{tabular}{lcc}
\hline \hline & $\begin{array}{c}\text { Exit } \\
(1)\end{array}$ & $\begin{array}{c}\text { Entry } \\
(2)\end{array}$ \\
\hline Women & -0.017 & $-0.034^{* * *}$ \\
& $(0.069)$ & $(0.0076)$ \\
$M P$ if Woman & 0.211 & $-0.110^{* *}$ \\
& $(0.273)$ & $(0.053)$ \\
$M P$ if Man & -0.068 & -0.097 \\
& $(0.164)$ & $(0.065)$ \\
\hline Constant & yes & yes \\
Other inter. terms & yes & yes \\
Financial var., lag & yes & yes \\
Demographics, lag & yes & yes \\
Household FE & yes & yes \\
Time FE & yes & yes \\
\hline Observations & 3649 & 11129 \\
Pseudo $R^{2}$ & 0.07 & 0.07 \\
\hline \hline
\end{tabular}

Note: This table presents results of a probit regression using the full sample from 2001 through 2017. The variable Exit is a dummy equal to 1 if the household exits the stock market in $t$ and 0 if it stays in; the variable Entry is a dummy equal to 1 if the household entries the stock market in $t$ and zero if it does not. The dummy Woman $_{i}$ is equal to one if the head of the household is single and female; zero if the household head is male. The variable $M P_{i, t}$ is the biennial household-level monetary policy shock series constructed in Section 3.1.2. The variable $M P_{i, t}^{*}$ is the interaction between $M P_{i, t}$ and the value of the household's lagged financial portfolio, $W_{i, t-1}$. Estimates are marginal effects evaluated at sample averages of the explanatory variables. Standard errors (in parentheses) are clustered at the household level. ${ }^{*},{ }^{* *}$, and ${ }^{* * *}$ represent statistical significance at the $10 \%, 5 \%$, and $1 \%$ levels. 
saving) or the price of the asset changes (passive saving or capital gain). ${ }^{12}$

Fortunately, PSID provides data that helps us visualize the active savings on two financial asset categories, which are stocks and cash. Regarding the asset category stocks, the households are asked to specify the amount of stocks they have purchased and sold from January of the period beginning two calendar years prior to the year of the survey. However, the PSID does not specifically collect data on the active savings of the asset category cash. This is because the PSID assumes that the riskless assets in this category do not bear any interest. Therefore, the active saving constitutes exclusively the change in value of this asset category between two waves.

Using this information, we examine the effect of monetary policy on the active savings of stocks and the asset category cash. For simplicity, we refer to riskless assets for the latter category, since it does not just include deposits, but also riskless Treasury bond investments. We employ a fixed effect model,

$$
\begin{aligned}
\mathrm{AS}_{i, t}= & \delta_{i}+\delta_{t}+\alpha X_{i, t-1}+\beta_{1} M P_{i, t}^{*}+\beta_{2}\left(M P_{i, t}^{*} \times \text { Woman }_{i}\right)+\beta_{3} M P_{i, t}+\beta_{4}\left(M P_{i, t} \times \text { Woman }_{i}\right) \\
& +\beta_{5} W_{i, t-1}+\beta_{6}\left(W_{i, t-1} \times \text { Woman }_{i}\right)+\beta_{7} \text { Woman }_{i}+\varepsilon_{i, t}
\end{aligned}
$$

where $\mathrm{AS}_{i, t}$ can be either the active net purchase amount of stocks or the riskless assets of household $i$ between $t-1$ and $t$. All covariates are the same as in the analysis for stock market participation. $\delta_{i}$ and $\delta_{t}$ are the individual- and time fixed effects, respectively, and vector $X_{i, t-1}$ includes the same financial and demographic characteristics as in the probit model. All remaining terms capture the three-way interaction effect. We are interested in the coefficients $\beta_{1}, \beta_{2}, \beta_{3}$, and $\beta_{4}$. Since we consider households that participate in the stock market, in this exercise we use the previous wave stock investment as the exposure variable for monetary policy $\left(W_{i, t-1}\right) .{ }^{13}$

Results are reported in Table 4. In columns (1) - (3) we present the results with active saving of stocks. For the remaining three columns (columns (4) - (6)), the dependent variable is the active saving of riskless assets. In addition, we analyze three distinct groups of households

\footnotetext{
${ }^{12}$ The PSID provides us with risky asset active saving and investment change, thus, in principle, we should be able to construct capital gains at least for the risky assets, as

$$
\text { Capital Gain } \text { risky asset }, t=\Delta \text { Risky Asset }_{t}-\text { Active Saving }_{\text {risky asset }, t} .
$$

There are three issues. First, transfers/inheritance of financial assets would be registered as capital gain instead of active saving, and this would systematically bias our capital gain measure. Second, household stock investment is measured with error and the same is certainly true for active saving. This implies that, for a given change stock wealth, a positive error in the active saving necessarily lowers passive saving by an equal amount, inducing a strong negative correlation between the two. This bias is especially serious in case of systematic under-reporting of trades (forgotten trades). In this case, PSID data would show a change in risky asset holding but no active trading and, thus, it would report all the difference as capital gains; this would also lead a strong negative correlation between change in risky asset investment and capital gains. Third, the PSID data does not provide information on the active saving of the total financial portfolio, thus it is not possible to calculate the capital gains for this category.

${ }^{13}$ As a robustness check, we also use the value of the financial portfolios of the previous wave as an exposure variable. The results in Appendix E are very similar to the baseline results.
} 
depending on the gender and marital status of the household head. First, we compare single female-headed households with all male-headed households (columns (1) and (4)). Afterwards, we analyze whether single women are different from married women by comparing single women with married male-headed households (columns (2) and (5)). Finally, in columns (3) and (6), we compare single men with married male-headed couples to examine whether these two groups react differently to monetary policy in a significant matter.

Let us first concentrate on the results for single women and all male-headed households in columns (1) and (4). Monetary policy seems to play an important role for the investment behavior of households. Interestingly, it is the monetary policy shocks interacted with the stock wealth exposure variable $\left(M P^{*}\right)$ that have a significant effect on the active savings of both stocks and riskless assets. Therefore, monetary policy itself does not have an effect, but only through its effect on households stock wealth. While the active saving of stocks decreases after a contractionary monetary policy shock, active saving of riskless assets increases. This result is consistent with the so-called portfolio rebalancing channel of monetary policy; a monetary tightening that increases the yields of financial assets induces investors to reduce the risk of their financial portfolio by shifting their investments from assets with higher expected return toward riskless assets. For the baseline model, we calculate the economic numbers of this effect: after a monetary policy shock that increase one-year Treasury yields by 100 basis points, on average investors sell stocks by roughly $760 \$$ (Column 1 ) and buy $5331 \$$ of riskless assets (Column 4). The small magnitude of the trading volume can be explained through the well-known trading inertia of households (Brunnermeier and Nagel, 2008). ${ }^{14}$ The other two models provide the same results, where the coefficients are larger and of higher significance.

Nevertheless, this effect seems to be gender-neutral as the coefficients attached to any of the terms that include the dummy $W_{o m a n}$ are not significant. This result indicates that once women participate in the stock market, woman's active saving decisions do not significantly differ from men's. This homogeneous response of women and men to monetary policy may be controversial to the literature that documents behavioral differences between women and men in the financial markets. Nevertheless, note that our results do not reject the fact that women and men invest heterogeneously, but rather provide evidence that women and men react to monetary policy in a homogeneous manner. Therefore, women and men seem to both understand the inverse relationship between the policy rates and asset prices, which can be related to a high level of financial literacy of the stock market participants, regardless of gender.

With the other sub-sample analysis, we also examine whether marital status influences how monetary policy influences investment behavior of households. For men, we are partly able to support the results of the baseline model. For stocks, we do not observe any significant differences between married men and single men (column (3)). However, for riskless assets, results show that single men purchase less riskless assets after a contractionary monetary policy shock compared

\footnotetext{
${ }^{14}$ The numbers are calculated by multiplying the coefficients with the average stock holdings $(252971.95 \$)$.
} 
to married men (column (6)). Nevertheless, if we compare single women with only married male-headed households (columns (2) and (5)), we obtain the same results as with the baseline model. These two groups do not significantly differ from each other.

Table 4: Monetary policy and active savings

\begin{tabular}{|c|c|c|c|c|c|c|}
\hline & \multicolumn{3}{|c|}{ Risky asset active saving } & \multicolumn{3}{|c|}{ Riskless asset active saving } \\
\hline & $\begin{array}{c}\text { Single women } \\
\text { VS } \\
\text { All men } \\
(1)\end{array}$ & $\begin{array}{l}\text { Single women } \\
\text { VS } \\
\text { Married men } \\
\text { (2) }\end{array}$ & $\begin{array}{c}\text { Single men } \\
\text { VS } \\
\text { Married men } \\
(3)\end{array}$ & $\begin{array}{c}\text { Single women } \\
\text { VS } \\
\text { All men } \\
(4)\end{array}$ & $\begin{array}{l}\text { Single women } \\
\text { VS } \\
\text { Married Man } \\
\text { (5) }\end{array}$ & $\begin{array}{c}\text { Single men } \\
\text { VS } \\
\text { Married men } \\
(6)\end{array}$ \\
\hline$M P$ & $\begin{array}{c}-215.482 \\
(7550.35)\end{array}$ & $\begin{array}{c}-136.063 \\
(7859.843)\end{array}$ & $\begin{array}{l}-1072.996 \\
(7867.129)\end{array}$ & $\begin{array}{l}-12135.760 \\
(47658.620)\end{array}$ & $\begin{array}{l}-26518.420 \\
(50506.810)\end{array}$ & $\begin{array}{l}-26752.710 \\
(48724.580)\end{array}$ \\
\hline$M P \times$ Gender/Marital Status & $\begin{array}{c}8776.583 \\
(7041.577)\end{array}$ & $\begin{array}{c}9222.198 \\
(7565.827)\end{array}$ & $\begin{array}{l}-2835.371 \\
(5766.392)\end{array}$ & $\begin{array}{c}-23028.370 \\
(41846.010)\end{array}$ & $\begin{array}{c}-34257.890 \\
(41653.660)\end{array}$ & $\begin{array}{c}16578.520 \\
(27658.250)\end{array}$ \\
\hline$M P^{*}$ & $\begin{array}{c}-0.003^{* *} \\
(0.001)\end{array}$ & $\begin{array}{c}-0.003^{* *} \\
(0.001)\end{array}$ & $\begin{array}{c}-0.003^{* *} \\
(0.001)\end{array}$ & $\begin{array}{c}0.092^{* * *} \\
(0.011)\end{array}$ & $\begin{array}{c}0.093^{* * *} \\
(0.011)\end{array}$ & $\begin{array}{c}0.100^{* * *} \\
(0,011)\end{array}$ \\
\hline$M P^{*} \times$ Gender/ Marital Status & $\begin{array}{c}0.046 \\
(0.036)\end{array}$ & $\begin{array}{c}0.053 \\
(0.042)\end{array}$ & $\begin{array}{c}0.186 \\
(0.016)\end{array}$ & $\begin{array}{l}-0.262 \\
(0.479)\end{array}$ & $\begin{array}{l}-0.067 \\
(0.524)\end{array}$ & $\begin{array}{c}-0.139^{* * *} \\
(0.045)\end{array}$ \\
\hline Constant & yes & yes & yes & yes & yes & yes \\
\hline Other inter. terms & yes & yes & yes & yes & yes & yes \\
\hline Financial var., lag & yes & yes & yes & yes & yes & yes \\
\hline Demographics, lag & yes & yes & yes & yes & yes & yes \\
\hline Household FE & yes & yes & yes & yes & yes & yes \\
\hline Time FE & yes & yes & yes & yes & yes & yes \\
\hline $\mathrm{N}$ & 2389 & 2236 & 2227 & 2455 & 2300 & 2290 \\
\hline$R^{2}$ & 0.01 & 0.01 & 0.01 & 0.06 & 0.05 & 0.04 \\
\hline
\end{tabular}

\section{Simulation study}

Our empirical analysis shows that monetary policy has gender-specific effects on the stock market entry decisions of US households. After a contractionary monetary policy shock that increases the 1-year US Treasury bond yields by 100 basis points, women are $11 \%$ less likely to enter the stock market, while men do not change their entry decisions due to a change in monetary policy stance. However, how large is this effect in terms of economic numbers?

In this section, we conduct a simulation exercise to visualize how the entry rate of single female-headed households was affected by monetary policy shocks during our sample period 2001 - 2017. Afterwards, we calculate how much financial wealth single women potentially missed out through non-participation, or gained through entry. We proceed in the following way. First, we aggregate the daily monetary policy shocks into biennial frequency and quantify the average effect 
of monetary policy on women's entry decisions. For this exercise, we do not use the householdspecific aggregated shocks, but sum the shocks from January 1st of wave $t-1$ to December 31 of wave $t$. Second, we use the stock market entry rate of single female-headed households from our data and calculate how high the entry rate would be if there were no monetary policy shocks. For example, if in 2011 the entry rate of single female-headed households is $10 \%$, and single women have been $5 \%$ less likely to enter the stock market due to monetary policy during this year, then the entry rate without monetary policy shocks is $0.1 \times(1+0.05)=0.105$.

Table 5 presents the biennial monetary policy shocks and the entry rates of single femaleheaded households with and without the monetary policy shocks. ${ }^{15}$ Interestingly, it seems that monetary policy in the USA has a contractionary nature in a biennially aggregated manner. Only during 2007-2009 did households experienced an expansionary monetary policy shock, which is the period after the Global Financial Crisis. Therefore, the entry rate of women has been rather negatively affected by monetary policy.

Table 5: Entry rate with and without monetary policy shocks

\begin{tabular}{l|ccl}
\hline \hline & Biennial MP shock & Entry rate & Entry rate without MP \\
\hline 2003 & 0.115 & 0.104 & 0.105 \\
2005 & 0.317 & 0.082 & 0.084 \\
2007 & 0.061 & 0.078 & 0.079 \\
2009 & -0.127 & 0.065 & 0.064 \\
2011 & 0.107 & 0.039 & 0.040 \\
2013 & 0.124 & 0.057 & 0.057 \\
2015 & 0.088 & 0.032 & 0.032 \\
2017 & 0.064 & 0.057 & 0.057 \\
\hline \hline
\end{tabular}

At first glance, the effect of monetary policy on the entry rates seems very marginal. However, how many single female-headed households are affected by this? How high are the capital gains that single women experience due to stock market entry (or non-entry)? According to Statista - a data portal of households - in the US there are about 9.5 million single-women households between

\footnotetext{
${ }^{15}$ These are entry rates that we calculate with the PSID data. We use weights to be able to have a representative sample of single female-headed households.
} 
25 and 65 years old. ${ }^{16}$ The red line in Figure 4 visualizes the number of single female-headed households that entered or did not enter the stock market due to monetary policy.

Figure 4: Accumulated capital gains/losses of single women through monetary policy

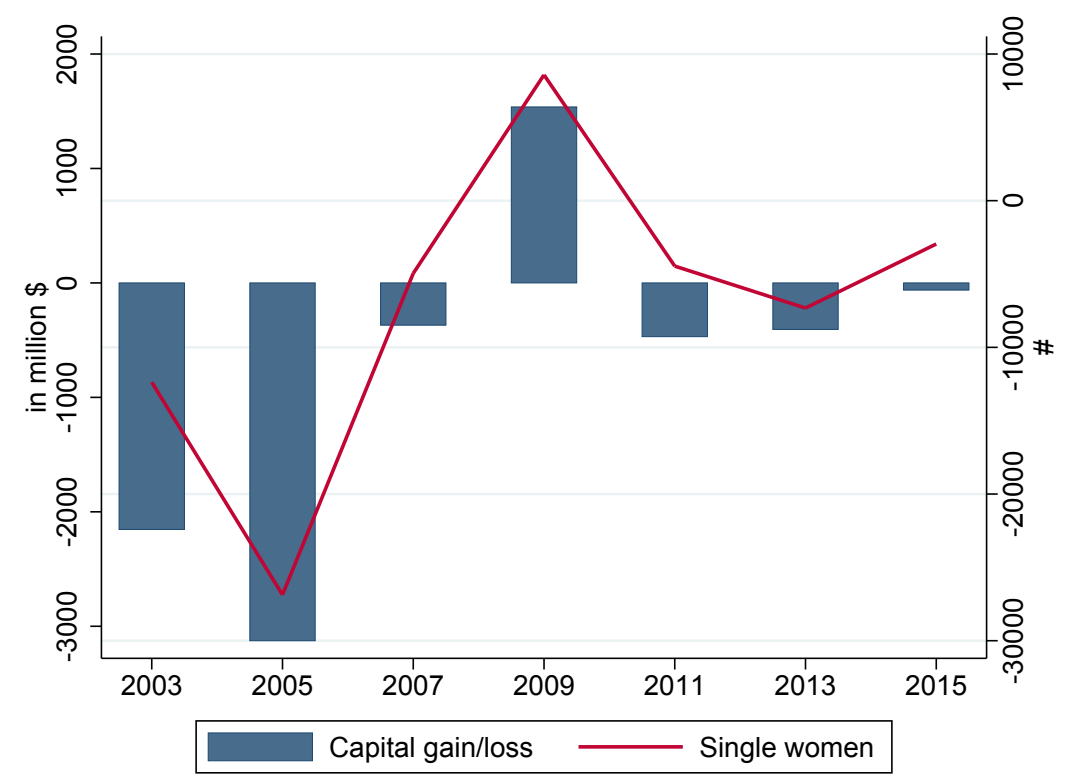

Note: According to the PSID, the average stock holdings of single female-headed households amount to $113215.46 \$$. We take this number and calculate for each period the average capital gains by multiplying this number with the growth rate of the S\&P 500 index.

As a next step, we calculate the accumulated capital gains that single female women experience through monetary policy. For this exercise, we use the average stock holding of single women stock market participants, which is $113215.46 \$$. We approximate capital gains of women by using the yearly average S\&P 500 index to proxy capital gains of households that participate in the stock market. Suppose you enter the stock market in the year 2003 and stay until 2017. The S\&P 500 index in 2003 was 500 and 2000 in 2017. Thus, the capital gain during this period is $(2000-500 / 500)=3$, or 300 percent. This means that if women entered the stock market in 2003 through monetary policy and assuming that they hold on average $113215.46 \$$ of stocks, the capital gain during this period is $339646.48 \$$. We calculate these capital gains from the stock market for every period until 2015. ${ }^{17}$ Afterwards, we multiply the capital gains with the number of single female-headed households that are affected by monetary policy. The blue bars in Figure 4 present the numbers.

According to the numbers in Figure 4, during times of larger contractionary monetary policy shocks, until the Global Financial Crisis of 2007/8, women were less likely to enter the stock market and thus missed out high capital gains in the stock market. The aggregated numbers

\footnotetext{
${ }^{16}$ Status of 2014 .

${ }^{17}$ For 2017, we do not have capital gains since the sample period ends in 2017.
} 
are quite significant, amounting to 3 billion $\$$. Compared to this, after the low interest rate environment, the missed out capital gains are much smaller. Nevertheless, we need to take into consideration that if these women, who did not enter the stock market due to monetary policy, continue to not participate in the stock market for a long time period, the missed capital gains will further increase.

In summary, we show that the effect of monetary policy on the stock market entry rate may seem somewhat small, however, that the missed out capital gains can be significantly large. Due to the fact that single female-headed households are the poorest group in the USA, this can have severe effects on the financial well-being of this group, thus potentially leading to a greater gender wealth gap in the long-run.

\section{Conclusion}

This paper investigates potential heterogeneous effects of monetary policy on stock market investment behavior across women and men using US household survey data covering 2001 through 2017 from the PSID. Our empirical analysis shows that the gender-specific impact of monetary policy on stock market investment behavior is only partial. On the one hand, contractionary monetary policy negatively affects women's stock market participation status (i.e. decreasing the probability of stock market entry), while this is not the case for men. On the other hand, monetary policy does not have a heterogeneous impact across women and men with regard to the decision to exit the stock market; or does it cause either to adjust their stock investment.

In summary, our results suggest that women are more sensitive to monetary policy cycles than men are. Our simulation study to visualize the missed out capital gains of stock market non-participation confirms the severe negative consequences for the gender wealth gap. This, in turn, can have consequences for the financial well-being of women, since high and stable female stock market participation enables women to receive high equity premiums, thus accumulating wealth in the long-run. Since our results show that monetary policy only affects the entry decisions of women, it is crucial to make women resilient to monetary policy adjustments. One relevant channel through which this can be achieved is financial literacy. Nevertheless, this is beyond the scope of this paper and represents an interesting avenue for future research. 


\section{References}

Adam, K. and Tzamourani, P. (2016). Distributional consequences of asset price inflation in the Euro area. European Economic Review, 89:172-192.

Agnew, J., Balduzzi, P., and Sunden, A. (2003). Portfolio choice and trading in a large 401(k) plan. American Economic Review, 93(1):193-215.

Ameriks, J. and Zeldes, S. P. (2004). How do household portfolio shares vary with age. Technical report, Columbia University Working Paper.

Ampudia, M., Georgarakos, D., Slacalek, J., Tristani, O., Vermeulen, P., and Violante, G. (2018). Monetary policy and household inequality. Working Paper Series 2170, European Central Bank.

Bakker, I. (1994). The strategic silence: Gender and economic policy. Technical report.

Barber, B. M. and Odean, T. (2001). Boys will be boys: Gender, overconfidence, and common stock investment. The Quarterly Journal of Economics, 116(1):261-292.

Bivens, J. (2015). Gauging the impact of the Fed on inequality during the Great Recession. Hutchins Center Working Papers.

Brunnermeier, M. K. and Nagel, S. (2008). Do wealth fluctuations generate time-varying risk aversion? Micro-evidence on individuals. American Economic Review, 98(3):713-36.

Bucher-Koenen, T. and Ziegelmeyer, M. (2013). Once burned, twice shy? Financial literacy and wealth losses during the financial crisis. Review of Finance, 18(6):2215-2246.

Cawthorne, A. (2008). The stright facts on women in poverty. Center for American Progress, $8: 1-3$.

Croson, R. and Gneezy, U. (2009). Gender differences in preferences. Journal of Economic literature, $47(2): 448-74$.

Daniel, K., Garlappi, L., and Xiao, K. (2018). Monetary policy and reaching for income. CEPR Working Paper No. 25344.

Deaton, A. (1997). The analysis of household surveys: A microeconometric approach to development policy. The World Bank.

Domanski, D., Scatigna, M., and Zabai, A. (2016). Wealth inequality and monetary policy. BIS Quarterly Review March.

Dwyer, P. D., Gilkeson, J. H., and List, J. A. (2002). Gender differences in revealed risk taking: Evidence from mutual fund investors. Economics Letters, 76(2):151-158.

Fisher, P. J. and Yao, R. (2017). Gender differences in financial risk tolerance. Journal of Economic Psychology, 61:191-202.

Guiso, L., Sapienza, P., and Zingales, L. (2018). Time varying risk aversion. Journal of Financial Economics, 128(3):403-421. 
Gürkaynak, R. S., Sack, B., and Swansonc, E. T. (2005). Do actions speak louder than words? The response of asset prices to monetary policy actions and statements. International Journal of Central Banking, 1.

Haliassos, M. and Bertaut, C. C. (1995). Why do so few hold stocks? The Economic Journal, 105(432):1110-1129.

Jianakoplos, N. A. and Bernasek, A. (1998). Are women more risk averse? Economic Inquiry, $36(4): 620-630$.

Lenza, M. and Slacalek, J. (2018). How does monetary policy affect income and wealth inequality? Evidence from the Euro area. European Central Bank, mimeo.

Lian, C., Ma, Y., and Wang, C. (2018). Low Interest Rates and Risk-Taking: Evidence from Individual Investment Decisions. The Review of Financial Studies, 32(6):2107-2148.

Malmendier, U. and Nagel, S. (2011). Depression babies: Do macroeconomic experiences affect risk taking? The Quarterly Journal of Economics, 126(1):373-416.

Nakamura, E. and Steinsson, J. (2018). High-frequency identification of monetary non-neutrality: The information effect. The Quarterly Journal of Economics, 133(3):1283-1330.

Piazzesi, M. and Swanson, E. T. (2008). Futures prices as risk-adjusted forecasts of monetary policy. Journal of Monetary Economics, 55(4):677-691.

Semega, J., Kollar, M., Creamer, J., and Mohanty, A. (2019). Income and poverty in the united states: 2018. Washington DC: US Government Printing Office.

Sunden, A. E. and Surette, B. J. (1998). Gender differences in the allocation of assets in retirement savings plans. The American Economic Review, 88(2):207-211.

Swanson, E. T. (2017). Measuring the effects of federal reserve forward guidance and asset purchases on financial markets. Technical report, National Bureau of Economic Research.

Van Staveren, I. (2014a). Economics after the crisis: An introduction to economics from a pluralist and global perspective. Routledge.

Van Staveren, I. (2014b). The lehman sisters hypothesis. Cambridge Journal of Economics, 38(5):995-1014.

Young, B. (2018). 17. financialization, unconventional monetary policy and gender inequality. Handbook on the International Political Economy of Gender. 


\section{Appendix}

\section{A Data}

Table 6: Summary statistics - unweighted sample

\begin{tabular}{|c|c|c|c|c|c|c|}
\hline & Mean & $\mathrm{SD}$ & Mean & $\mathrm{SD}$ & Mean & $\mathrm{SD}$ \\
\hline & \multicolumn{2}{|c|}{ All } & \multicolumn{2}{|c|}{ Women } & \multicolumn{2}{|c|}{ Men } \\
\hline \multicolumn{7}{|l|}{ Panel A: All households } \\
\hline Stock market exit & 0.33 & 0.47 & 0.39 & 0.49 & 0.32 & 0.47 \\
\hline Stock market entry & 0.09 & 0.29 & 0.06 & 0.23 & 0.10 & 0.30 \\
\hline Stock market part. & 0.23 & 0.42 & 0.12 & 0.33 & 0.25 & 0.43 \\
\hline Stock holding & 41225.61 & 545474.93 & 9226.45 & 75603.48 & 46975.97 & 591304.09 \\
\hline Riskless holding & 22894.65 & 78762.07 & 10111.35 & 27983.65 & 25163.57 & 84503.71 \\
\hline Stock active saving & 240986.52 & 12062381.55 & 205432.69 & 10481270.23 & 247823.64 & 12335552.57 \\
\hline Riskless active saving & 4980.50 & 79403.64 & 1052.36 & 26494.25 & 5673.18 & 85480.07 \\
\hline Stock share & 0.13 & 0.28 & 0.07 & 0.22 & 0.14 & 0.29 \\
\hline$\Delta$ Stock share & -0.01 & 0.27 & 0.00 & 0.21 & -0.01 & 0.28 \\
\hline Financial wealth & 77781.49 & 613284.96 & 28763.40 & 162369.97 & 86579.55 & 662079.63 \\
\hline Net worth & 300973.88 & 1180274.72 & 140516.41 & 1030338.20 & 329636.15 & 1203852.51 \\
\hline Income & 88062.41 & 111588.71 & 44404.58 & 34914.10 & 95799.12 & 118539.65 \\
\hline Home ownership & 0.82 & 0.39 & 0.62 & 0.49 & 0.85 & 0.36 \\
\hline College degree & 0.43 & 0.50 & 0.43 & 0.49 & 0.43 & 0.50 \\
\hline Employed & 0.90 & 0.30 & 0.87 & 0.34 & 0.90 & 0.30 \\
\hline Observations & 17496 & & 2628 & & 14837 & \\
\hline \multicolumn{7}{|c|}{ Panel B: Stock market participants } \\
\hline Stock holding & 225329.34 & 1347519.14 & 94468.94 & 247749.63 & 235573.54 & 1396764.47 \\
\hline Riskless holding & 53373.19 & 146875.34 & 31682.75 & 53956.23 & 55076.49 & 151616.12 \\
\hline Stock active saving & 3421.39 & 31033.94 & -207.80 & 5844.05 & 3705.44 & 32168.53 \\
\hline Riskless active saving & 12196.13 & 148708.05 & 4923.89 & 51471.68 & 12765.47 & 153712.16 \\
\hline Stock share & 0.59 & 0.30 & 0.59 & 0.31 & 0.59 & 0.29 \\
\hline$\Delta$ Stock share & 0.01 & 0.30 & 0.00 & 0.30 & 0.01 & 0.30 \\
\hline Financial wealth & 308648.77 & 1485082.53 & 150920.92 & 368328.37 & 321018.26 & 1537715.64 \\
\hline Net worth & 808553.83 & 2160744.22 & 792217.26 & 3523859.95 & 810332.24 & 2018914.54 \\
\hline Income & 139634.08 & 193253.61 & 63216.63 & 70290.99 & 145537.43 & 198467.16 \\
\hline Home ownership & 0.93 & 0.26 & 0.86 & 0.35 & 0.93 & 0.25 \\
\hline College degree & 0.68 & 0.47 & 0.72 & 0.45 & 0.67 & 0.47 \\
\hline Employed & 0.91 & 0.29 & 0.86 & 0.35 & 0.91 & 0.28 \\
\hline Observations & 2771 & & 198 & & 2571 & \\
\hline
\end{tabular}

Note: The table shows the summary statistics of the relevant wealth and income variables included in the analysis, in Panel A for the full sample; in Panel B for the subsample of participant households (at least $\$ 1$ invested in stock in both $t-1$ and $t$ ). The sample period is 2003-2017. The wealth and income variables are deflated by the CPI into December 2001. Source: PSID 


\section{B Reference period of the survey questions}

In this section, we concentrate on some important timing issues of the PSID data that pose several difficulties for our empirical analysis. Unfortunately, the reference period of the survey questions does not match for all variables in the PSID. Thus, a careful inspection of the reference period of the variables of interest is crucial for a correct empirical analysis. For instance, to gather data on wealth, interviewers ask the households for the current value of the their asset holdings. However, for income data, households are asked to report their annual income of two years ago.

In addition, it is very important to acknowledge that the PSID interviews the households every other year over the approximate window of March and November, see Figure 5. We can see that most interviews take place during March and June. Since all survey questions regarding households' wealth are always directed to the time of the interview, this means that our data on wealth is also dispersed across time.

Figure 5: Distribution of PSID interview months, $2003-2017$

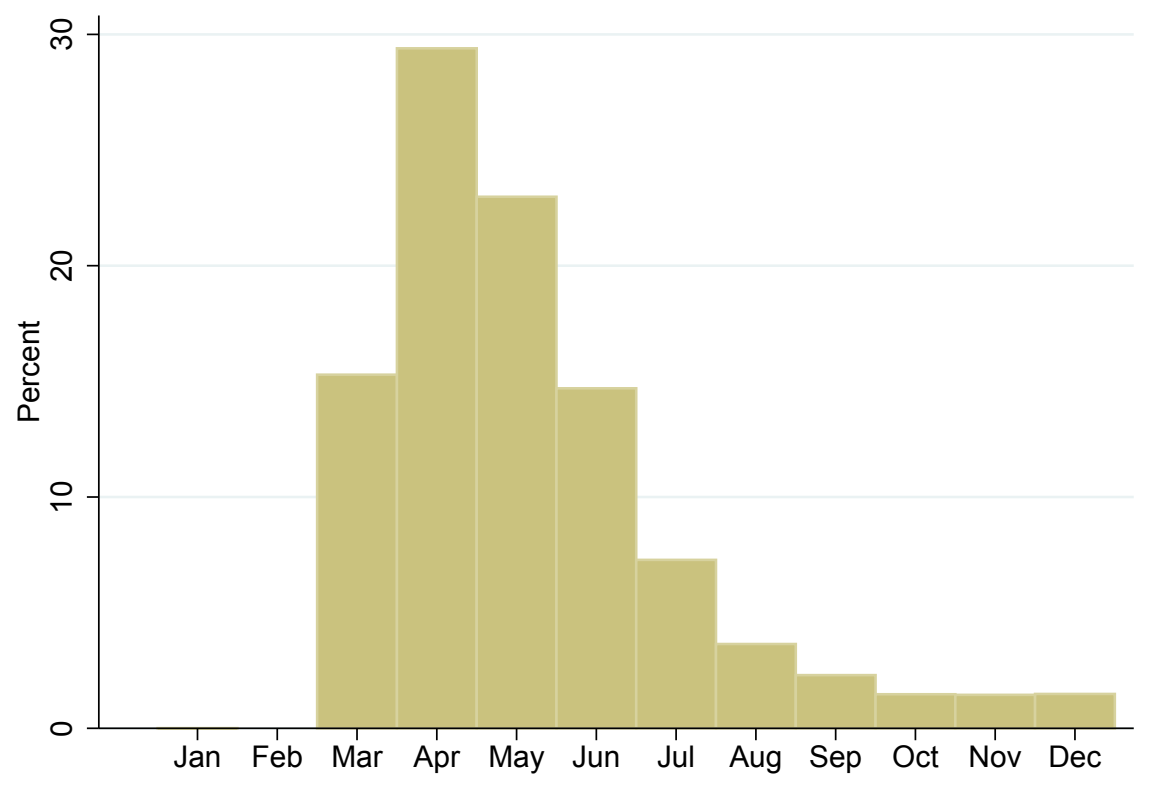

Note: This figure shows the cross sectional distribution of PSID interviews over the year 2003 - 2017. Source: PSID

It is also worth mentioning the specific reference period of the variables regarding the active savings of stocks. According to the survey questions, households are asked to report the net sales and purchases of stocks from January of the period beginning two calendar years prior to the year of the survey. This imposes potential problems for our analysis since the reference period of the active purchases of stocks does not match with those of the value of stock wealth.

Recall that, in our baseline model, we aggregate the daily monetary policy shocks between the current and previous interview dates to capture the household-specific information set of monetary policy shocks that households experienced between the two interview dates. By multiplying this monetary policy shock set with the previous value of stock wealth, we are able to additionally 
identify how monetary policy shocks affect the stock market investment behavior of households by having an exogenous effect on the value of their previous stock wealth. However, in the case where we are interested in the effect of monetary policy (with the exposure variable) on the active savings of stocks, the information content of the aggregated monetary policy shocks does not match with the reference period of the active savings.

Unfortunately, there is no optimal way to overcome this problem, since it is impossible to match the reference period of the active saving variable and the value of stock wealth. If we match the reference period of the aggregated monetary policy shocks to the active saving of stocks, then we would have a problem with the exposure variable. Therefore, we proceed in the following way: first, we aggregate the monetary policy shocks from January of the previous wave until the interview month of the current wave. Thereafter, we estimate an exposure variable of the correct reference period, which is the value of the households' stock wealth in January of the previous wave. We approximate this by linearly interpolating the stock wealth of the previous wave with those of two waves before. For example, assume a household reported the value of their stock wealth in March 2003 to be 150 USD and in March 2001 it was 100 USD. If we are interested in estimating the value of stock wealth in January 2003, we can calculate it as $100 \times \frac{150-100}{24} \times 21=143.75$. In Table 7 we present the results of our robustness exercise. In addition to stock wealth, we also use the value of the total financial portfolio as an exposure variable. 
Table 7: Monetary policy and active savings with aggregated monetary policy starting from January

\begin{tabular}{lcc}
\hline \hline & $\begin{array}{c}\text { Stock wealth } \\
(1)\end{array}$ & $\begin{array}{c}\text { Total financial wealth } \\
(2)\end{array}$ \\
\hline$M P$ & 61906.860 & 49663.190 \\
& $(44450.500)$ & $(46593.630)$ \\
$M P \times$ Women & 2341.284 & 2874.955 \\
& $(5347.921)$ & $(4571.898)$ \\
$M P^{*}$ & -0.007 & $-0.002^{* *}$ \\
& $(0.012)$ & $(0.000)$ \\
$M P^{*} \times$ Women & $0.066^{*}$ & 0.043 \\
& $(0.034)$ & $(0.028)$ \\
\hline Constant & yes & yes \\
Other inter. terms & yes & yes \\
Financial var., lag & yes & yes \\
Demographics, lag & yes & yes \\
Household FE & yes & yes \\
Time FE & yes & yes \\
\hline N & 2,237 & 2,244 \\
$R^{2}$ & 0.01 & 0.01 \\
\hline
\end{tabular}

Note: This table presents results of a fixed effect model using the sub-sample of households participating in the stock market between 2005-2017. The dependent variable is active savings of stocks. The dummy Woman $_{i}$ is equal to 1 if the head of the household is single and female, zero if the household head is male. Here, the variable $M P_{i, t}$ is the household-level biennial monetary policy shock series aggregated from January of the previous wave until the current date of the interview. The variable $M P_{i, t}^{*}$ is the interaction between $M P_{i, t}$ and the household's lagged liquid wealth of January that we interpolate. Standard errors (in parentheses) are clustered at the household level. ${ }^{*},{ }^{* *}$, and ${ }^{* * *}$ represent statistical significance at the $10 \%, 5 \%$, and $1 \%$ levels.

\section{Monetary policy shock identification}

The identification method of Nakamura and Steinsson (2018) employs high frequency data on interest rate futures to construct a monetary policy shock measure. It identifies the exogenous and unanticipated component of Fed's announcements (the "shock") by extracting it directly from financial market responses. The identification strategy relies on measuring the change in the futures during a narrow time window around FOMC meetings. The idea is that right before any meeting, all public available information of the economy is already incorporated into 
the financial markets and reflected in their prices/yields. Thus, if the time span around the FOMC announcement is tight enough, any immediate change in the futures is dominated by the information about future monetary policy contained in the announcement itself. Moreover, by using a broad range of interest rate futures, the measure captures not only unanticipated changes in the Fed funds rate, but also the effect of "forward guidance."

Nakamura and Steinsson (2018) construct the monetary policy news shock as the first principal component of the change in five interest rate futures. The first of these is the change in market expectations of federal funds rates during a narrow time window around FOMC meetings. In general, the payout of the federal funds futures is calculated as the average effective federal funds rate that prevails over the calendar month specified in the contract. Therefore, immediately before an FOMC meeting at time $t-\Delta t$, the current-month federal funds future contract can be written as the weighted average of (i) the federal funds rate of the month $r_{0}$ (before the FOMC meeting) and (ii) the rate that is expected to prevail for the remainder of the month $r_{1}$,

$$
f f 1_{t-\Delta t}=\frac{d 1}{D 1} r_{0}+\frac{D 1-d 1}{D 1} E_{t-\Delta t}\left(r_{1}\right),
$$

where $d 1$ denotes the day of the FOMC meeting, $D 1$ is the number of days in the month. ${ }^{18}$ Accordingly, the current-month federal funds rate contract right after the FOMC meeting is,

$$
f f 1_{t}=\frac{d 1}{D 1} r_{0}+\frac{D 1-d 1}{D 1} E_{t}\left(r_{1}\right) .
$$

Thus, the change in expectations before and after the FOMC meeting can be calculated as

$$
m p 1_{t} \equiv E_{t}\left(r_{1}\right)-E_{t-\Delta t}\left(r_{1}\right)=\left(f f 1_{t}-f f 1_{t-\Delta t}\right) \frac{D 1}{D 1-d 1} .
$$

The second variable we use is the change in expectations regarding the federal funds rate target after the second FOMC meeting. We apply the same method:

$$
f f 2_{t-\Delta t}=\frac{d 2}{D 2} E_{t-\Delta t}(r 1)+\frac{D 2-d 2}{D 2} E_{t-\Delta t}(r 2),
$$

where $d 2$ and $D 2$ are the day of that FOMC meeting and the number of days in the month containing that FOMC meeting, respectively. ${ }^{19}$ Again, using the same calculations as above, we are able to calculate the change in expectations at the time of the next scheduled FOMC meeting,

$$
m p 2_{t} \equiv E_{t}\left(r_{2}\right)-E_{t-\Delta t}\left(r_{2}\right)=\left[\left(f f 2_{t}-f f 2_{t-\Delta t}-\frac{d 2}{D 2} m p 1_{t}\right)\right] \frac{D 2}{D 2-d 2} .
$$

The last set of interest rate futures we use are the change in the price of three Eurodollar futures at the time of the FOMC meetings. Following Nakamura and Steinsson (2018), we use the Eurodollar futures at horizons of two, three, and four quarters in the future.

Since only daily data is available to us, we are not able to construct the monetary policy news shock within a 30-minute window. This can affect the exogeneity of our measure due

\footnotetext{
${ }^{18}$ Note that Gürkaynak et al. (2005) introduce a risk premium term in the equation. For simplicity, we exclude this term.

${ }^{19}$ The next scheduled FOMC meeting can occur between the next month up to three months after the current meeting.
} 
to a wider time span around the FOMC meetings. Nevertheless, Piazzesi and Swanson (2008) show that a daily window is sufficient to identify exogenous components of monetary policy announcements. As a robustness check, we download the publicly available monetary policy shock series of Nakamura and Steinsson (2018), which stops in 2015 (our sample is until 2017) and apply them to our empirical analysis. The results remain robust. ${ }^{20}$

\section{Additional results}

\section{D.1 Conventional vs. unconventional monetary policy}

On December 16, 2008, the federal funds rate - the conventional monetary policy instrument of the Federal Reserve - reached the effective zero lower bound. Subsequently, the Federal Reserve introduced unconventional monetary policy measures in the attempt to further lower the long-term interest rates of the economy, thus boosting the stagnated economy. The two main unconventional tools that the Federal Reserve used are "forward guidance" and "large scale asset purchases."

Fortunately, the method of Nakamura and Steinsson (2018) captures the exogenous response of financial market participants coming from both conventional and unconventional monetary policies. This is useful since our sample period includes this period of unconventional monetary policy measures and, thus, we do not miss any important monetary policy interventions that are not related to a decrease in the (conventional) policy rate. However, this method does not allow us to disentangle between these two distinct monetary policy instruments.

In this section of the appendix, we investigate whether conventional and unconventional monetary policies have comparable effects on household's intensive margin portfolio decisions. We make use of the high frequency identification method of Swanson (2017), which disentangles between three distinct dimensions of monetary policy shocks. As in Nakamura and Steinsson (2018), Swanson (2017) uses a broad range of interest rate futures changes around FOMC announcements. The main difference is that, instead of extracting one principal component, this method extracts the first three principal components and rotates them to give the factors a structural interpretation. The first factor captures the surprise change in the federal funds rate target ("target shock"), the second is the surprise change in forward guidance ("forward guidance shock"), and the third is interpreted as surprise change in LSAPs ("LSAP shock"). For our purposes, we use only the target shock, which captures the conventional part of monetary policy. Figure 6 plots the target shock with our monetary policy news shock of Nakamura and Steinsson (2018). We scale it such that it has a 100 basis points effect on the one-year Treasury yield to make the estimates comparable to our baseline model. Table 8 shows the results.

The effect of the target shock on the active savings of stocks is identical to the effect of the monetary policy news shock (the coefficients are the same). After a one-unit contractionary monetary policy shock, households sell stocks by approximately $\$ 710$. The effect on the active savings of riskless assets has also the same sign, but the magnitude is smaller (0.051 vs. 0.0917). In economic numbers, this is a positive purchase of approximately $\$ 12900$. Therefore, we confirm that conventional- and unconventional monetary policies have similar effects on the investment behavior of households. Moreover, consistent with the baseline results, gender of the head does not play a role in the way households react to conventional shocks.

\footnotetext{
${ }^{20}$ Results are not reported here but are available upon request.
} 
Table 8: Monetary policy and active saving - target shock

Stock Act. Sav. Riskless Act. Sav.

(1)

(2)

\begin{tabular}{lcc}
\hline$M P$ & -3493.852 & -6170.350 \\
& $(2771.990)$ & $(18573.850)$ \\
$M P \times$ Women & 4398.834 & 8687.038 \\
& $(3501.916)$ & $(22893.520)$ \\
$M P^{*}$ & $-0.003^{* *}$ & $0.052^{* * *}$ \\
& $(0.001)$ & $(0.007)$ \\
$M P^{*} \times$ Women & 0.015 & $-0.545^{*}$ \\
& $(0.020)$ & $(0.318)$ \\
\hline Constant & yes & yes \\
Other inter. terms & yes & yes \\
Financial var., lag & yes & yes \\
Demographics, lag & yes & yes \\
Household FE & yes & yes \\
Time FE & yes & yes \\
\hline $\mathrm{N}$ & 2389 & 2455 \\
$R^{2}$ & 0.01 & 0.03 \\
\hline \hline
\end{tabular}

Note: This table presents the results of a fixed effect model using the sub-sample of households participating in the stock market over the years 2001-2017. The dependent variable is the stock active saving (column (1)) and the riskless asset active saving (column (2)). The dummy Woman $i$ is equal to 1 if the head of the household is single and female, and 0 if the household head is male. The variable $M P_{i, t}$ is the household-level biennial monetary policy shock series constructed in Section 3.1.3. The variable $M P_{i, t}^{*}$ is the interaction between $M P_{i, t}$ and the household's lagged stock holding, $W_{i, t-1}$. Standard errors (in parentheses) are clustered at the household level. ${ }^{*},{ }^{* *}$, and ${ }^{* * *}$ represent statistical significance at the $10 \%, 5 \%$, and $1 \%$ levels. 
Figure 6: The target shock and the monetary policy news shock, $2001-2017$

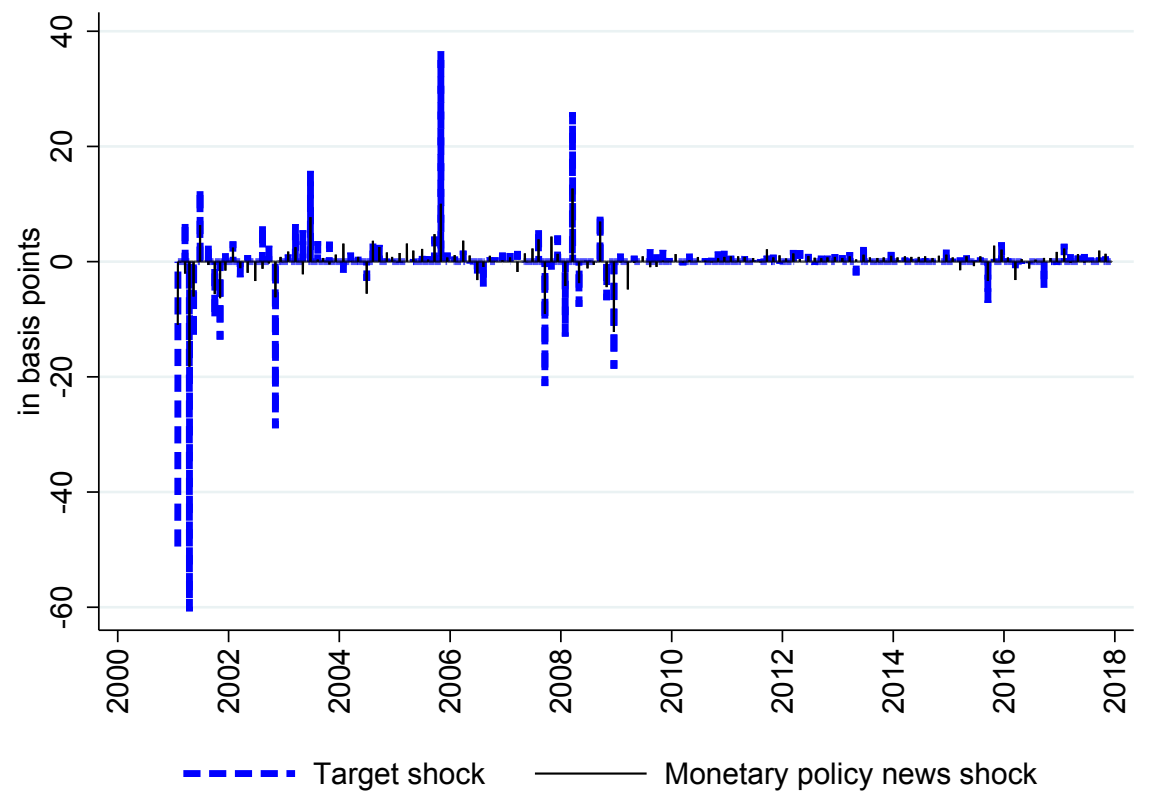

Note: This figure shows the monetary shocks estimated at a daily frequency over the $2001-2017$ period. The monetary policy shocks scaled to have a 100 b.p. impact on the 1-year US Treasury yield.

\section{D.2 Gender and wealth}

One might suspect that the absence of a gender-specific response to monetary policy is driven by the investment decisions of wealthier female and male investors. In fact, differences in risk aversion, inertia, and financial literacy across gender could progressively decline for increasing values of financial investment. This, in turn, would increase the chance that women and men at the top of the financial wealth distribution react homogeneously to monetary shocks, therefore influencing the direction and magnitude of our estimates.

In order to examine this hypothesis, we repeat our baseline analysis with two sub-samples. For women and men separately, we divide the households into two groups regarding their financial wealth. In panel $A$ we compare women and men in the top $50 \%$ of the financial wealth distribution and in panel $B$ we analyze women and men in the bottom $50 \%$ of the distribution.

Results are reported in Table 9. Let us first concentrate on Panel $A$. The coefficients are very similar, both in sign and magnitude, to our baseline estimates presented in Table 4 (columns (1) and (4)). This confirms our hypothesis that the wealthier women and men are, the more similar they become with regard to their investment behavior. Compared to this, the picture of the bottom $50 \%$ is quite different. Monetary policy has a gender-specific effect on the active savings of stocks and riskless assets, where women react more strongly than men. Nonetheless, the $R^{2}$ in Panel B are extremely low, suggesting that the explanatory power of all terms capturing monetary policy and all other covariates is virtually zero. 
Table 9: Monetary Policy and active savings - investors at the top and bottom of their respective financial wealth distribution

Stock Act. Sav. Riskless Act. Sav.

(1)

(2)

Panel A: Top 50\% of the financial wealth distribution

\begin{tabular}{lcc}
$M P$ & 5196.225 & 12706.640 \\
$M P \times$ Woman & $(14382.510)$ & $(109976.600)$ \\
& 25476.530 & -40239.630 \\
$M P^{*}$ & $(20166.780)$ & $(167046.200)$ \\
& $-0.004^{* *}$ & $0.095^{* * *}$ \\
$M P^{*} \times$ Woman & $(0.002)$ & $(0.011)$ \\
& 0.015 & -0.287 \\
Observations & $(0.068)$ & $(0.984)$ \\
$R^{2}$ & 1189 & 1224 \\
\hline
\end{tabular}

Panel B: Bottom 50\% of the financial wealth distribution

\begin{tabular}{lcc}
$M P$ & $-7073.196^{* *}$ & 9062.629 \\
& $(3410.666)$ & $(23157.800)$ \\
$M P \times$ Woman & $-4198.427^{*}$ & $-36786.480^{* *}$ \\
& $(2147.065)$ & $(16833.620)$ \\
$M P^{*}$ & 0.002 & 0.011 \\
& $(0.013)$ & $(0.114)$ \\
$M P^{*} \times$ Woman & 0.148 & 0.322 \\
& $(0.199)$ & $(0.400)$ \\
\hline Observations & 1220 & 1231 \\
$R^{2}$ & 0.00 & 0.00 \\
\hline \hline
\end{tabular}

Note: The dummy $W_{o m a n}$ is equal to 1 if the head of the household is single and female, 0 if the household head is male. The variable $M P_{i, t}$ is the household-level biennial monetary policy shock series constructed in Section 3.1.3. The variable $M P_{i, t}^{*}$ is the interaction between $M P_{i, t}$ and the household's lagged stock holding, $W_{i, t-1}$. Standard errors (in parentheses) are clustered at the household level. ${ }^{*},{ }^{* *}$, and ${ }^{* * *}$ represent statistical significance at the $10 \%, 5 \%$, and $1 \%$ levels. 


\section{E Robustness checks}

Table 10: Monetary policy and stock market exit and entry, single men vs. married couples

\begin{tabular}{lcc}
\hline \hline & $\begin{array}{c}\text { Exit } \\
(1)\end{array}$ & $\begin{array}{c}\text { Entry } \\
(2)\end{array}$ \\
& $\begin{array}{l}\text {-0.023 } \\
\text { Single man }\end{array}$ & $\begin{array}{c}-0.043^{* * *} \\
(0.043)\end{array}$ \\
& 0.422 & $-0.095)$ \\
$M P$ if Single man & $(0.258)$ & $(0.068)$ \\
& & \\
$M P$ if Married couple & -0.074 & -0.107 \\
& $(0.173)$ & $(0.074)$ \\
& yes & yes \\
Constant & yes & yes \\
Other inter. terms & yes & yes \\
Financial var., lag & yes & yes \\
Demographics, lag & yes & yes \\
Household FE & yes & yes \\
Time FE & 3388 & 9285 \\
\hline Observations & 0.07 & 0.06 \\
Pseudo $R^{2}$ & \\
\hline \hline
\end{tabular}

Note: This table presents results of a probit regression using the full sample over the 2001-2017 period. The dependent variable is a dummy equal to one if a household exits (column (1)) or enters (column (2)) the stock market, and 0 otherwise. The dummy $W_{o m a n}$ is equal to one if the head of the household is single and female, and zero if the household head is male. The variable $M P_{i, t}$ is the biennial household-level monetary policy shock series constructed in Section 3.1.2. The variable $M P_{i, t}^{*}$ is the interaction between $M P_{i, t}$ and the household's lagged liquid asset holding, $W_{i, t-1}$. Standard errors (in parentheses) are clustered at the household level. *, ${ }^{* *}$, and *** represent statistical significance at the $10 \%$, $5 \%$, and $1 \%$ levels. 
Table 11: Monetary policy and stock market exit and entry, single women vs. married men

\begin{tabular}{|c|c|c|}
\hline & $\begin{array}{l}\text { Exit } \\
(1)\end{array}$ & $\begin{array}{c}\text { Entry } \\
(2)\end{array}$ \\
\hline Women & $\begin{array}{l}-0.027 \\
(0.070)\end{array}$ & $\begin{array}{c}-0.045^{* * *} \\
(0.008)\end{array}$ \\
\hline$M P$ if Woman & $\begin{array}{c}0.248 \\
(0.275)\end{array}$ & $\begin{array}{c}-0.105^{* *} \\
(0.050)\end{array}$ \\
\hline$M P$ if Man & $\begin{array}{l}-0.047 \\
(0.169)\end{array}$ & $\begin{array}{l}-0.107 \\
(0.069)\end{array}$ \\
\hline Constant & yes & yes \\
\hline Other inter. terms & yes & yes \\
\hline Financial var., lag & yes & yes \\
\hline Demographics, lag & yes & yes \\
\hline Household FE & yes & yes \\
\hline Time FE & yes & yes \\
\hline Observations & 3,437 & 10339 \\
\hline Pseudo $R^{2}$ & 0.08 & 0.07 \\
\hline
\end{tabular}

Note: This table presents results of a probit regression using the full sample over the 2001-2017 period. The dependent variable is a dummy equal to one if a household exits (column (2)) or enters (column (3)) the stock market, and 0 otherwise. The dummy Woman $_{i}$ is equal to one if the head of the household is single and female, and zero if the household head is male. The variable $M P_{i, t}$ is the biennial household-level monetary policy shock series constructed in Section 3.1.2. The variable $M P_{i, t}^{*}$ is the interaction between $M P_{i, t}$ and the household's lagged liquid asset holding, $W_{i, t-1}$. Standard errors (in parentheses) are clustered at the household level. ${ }^{*},{ }^{* *}$, and ${ }^{* * *}$ represent statistical significance at the $10 \%$, $5 \%$, and $1 \%$ levels. 
Table 12: Monetary policy and active saving - alternative exposure variable

Stock Act. Sav. Riskless Act. Sav.

(1)

(2)

\begin{tabular}{lcc}
\hline$M P$ & 225.492 & -16195.050 \\
& $(7494.998)$ & $(42829.070)$ \\
$M P \times$ Women & 4689.360 & $-26253-070$ \\
& $(6355.601)$ & $(55193.950)$ \\
$M P^{*}$ & $-0.002^{*}$ & $0.088^{* * *}$ \\
& $(0.001)$ & $(0.012)$ \\
$M P^{*} \times$ Women & $0.065^{* *}$ & -0.046 \\
& $(0.029)$ & $(0.548)$ \\
Constant & yes & yes \\
Other inter. terms & yes & yes \\
Financial var., lag & yes & yes \\
Demographics, lag & yes & yes \\
Household FE & yes & yes \\
Time FE & yes & yes \\
\hline $\mathrm{N}$ & 2,389 & 2,455 \\
$R^{2}$ & 0.01 & 0.05 \\
\hline \hline
\end{tabular}

Note: This table presents results of a fixed effect model using the sub-sample of households participating in the stock market over the 2003-2017 period. The dependent variable is the stock active saving (column 1) and the riskless asset active saving (column 2). The dummy $W_{o m a n}$ is equal to 1 if the head of the household is single and female, zero if the household Head is male. The variable $M P_{i, t}$ is the household-level biennial monetary policy shock series constructed in Section 3.1.3. The variable $M P_{i, t}^{*}$ is the interaction between $M P_{i, t}$ and the household's lagged value of the total financial portfolio, $W_{i, t-1}$. Standard errors (in parentheses) are clustered at the household level. ${ }^{*},{ }^{* *}$, and ${ }^{* * *}$ represent statistical significance at the $10 \%, 5 \%$, and $1 \%$ levels. 
Table 13: Monetary Policy and active saving - only households that stay in the survey for at least two consecutive year

Stock Act. Sav. Riskless Act. Sav.

(1)

(2)

\begin{tabular}{lcc}
\hline$M P$ & -1515.470 & -30977.060 \\
& $(6344.462)$ & $(54717.170)$ \\
$M P \times$ Women & 6775.603 & 14073.240 \\
& $(6027.104)$ & $(37125.820)$ \\
$M P^{*}$ & $-0.002^{*}$ & $0.091^{* * *}$ \\
& $(0.001)$ & $(0.010)$ \\
$M P^{*} \times$ Women & 0.058 & -0.469 \\
& $(0.036)$ & $(0.433)$ \\
Constant & yes & yes \\
Other inter. terms & yes & yes \\
Financial var., lag & yes & yes \\
Demographics, lag & yes & yes \\
Household FE & yes & yes \\
Time FE & yes & yes \\
\hline $\mathrm{N}$ & 2660 & 2730 \\
$R^{2}$ & 0.01 & 0.02 \\
\hline \hline
\end{tabular}

Note: This table presents results of a fixed effect model using the sub-sample of households participating in the stock market over the 2003-2017 period. The dependent variable is the stock active saving (column 1) and the riskless asset active saving (column 2). The dummy $W_{o m a n}$ is equal to 1 if the head of the household is single and female, zero if the household head is male. The variable $M P_{i, t}$ is the household-level biennial monetary policy shock series constructed in section 3.1.3. The variable $M P_{i, t}^{*}$ is the interaction between $M P_{i, t}$ and the household's lagged liquid wealth, $W_{i, t-1}$. Standard errors (in parentheses) are clustered at the household level. ${ }^{*},{ }^{* *}$, and ${ }^{* * *}$ represent statistical significance at the $10 \%, 5 \%$, and $1 \%$ levels. 